\title{
Multiple Sclerosis: Immunopathology and Treatment Update
}

\author{
Narges Dargahi ${ }^{1}$, Maria Katsara ${ }^{2}$, Theodore Tselios ${ }^{3}$, Maria-Eleni Androutsou ${ }^{4}$, \\ Maximilian de Courten ${ }^{1}$ (D), John Matsoukas ${ }^{5}$ and Vasso Apostolopoulos $1, *$ (1) \\ 1 Centre for Chronic Disease, College of Health and Biomedicine, Victoria University, Melbourne VIC 3030, \\ Australia; narges.dargahi@live.vu.edu.au (N.D.); Maximilian.deCourten@vu.edu.au (M.d.C.) \\ 2 Medical Department, Novartis (Hellas) SACI, Metamorphosis, Athens 14452, Greece; \\ maria.katsara@novartis.com \\ 3 Department of Chemistry, University of Patras, Rio, Patras 26500, Greece; ttselios@upatras.gr \\ 4 Vianex S.A., Metamorphosis, Attikis, Athens 14451, Greece; AndroutsouM@vianex.gr \\ 5 ELDrug S.A., Patras Science Park, Platani, Patras 26504, Greece; imats1953@gmail.com \\ * Correspondence: vasso.apostolopoulos@vu.edu.au; Tel.: +61-3-9919-2025
}

Academic Editor: Evanthia Bernitsas

Received: 25 June 2017; Accepted: 3 July 2017; Published: 7 July 2017

\begin{abstract}
The treatment of multiple sclerosis (MS) has changed over the last 20 years. All immunotherapeutic drugs target relapsing remitting MS (RRMS) and it still remains a medical challenge in MS to develop a treatment for progressive forms. The most common injectable disease-modifying therapies in RRMS include $\beta$-interferons $1 \mathrm{a}$ or $1 \mathrm{~b}$ and glatiramer acetate. However, one of the major challenges of injectable disease-modifying therapies has been poor treatment adherence with approximately $50 \%$ of patients discontinuing the therapy within the first year. Herein, we go back to the basics to understand the immunopathophysiology of MS to gain insights in the development of new improved drug treatments. We present current disease-modifying therapies (interferons, glatiramer acetate, dimethyl fumarate, teriflunomide, fingolimod, mitoxantrone), humanized monoclonal antibodies (natalizumab, ofatumumab, ocrelizumab, alemtuzumab, daclizumab) and emerging immune modulating approaches (stem cells, DNA vaccines, nanoparticles, altered peptide ligands) for the treatment of MS.
\end{abstract}

Keywords: multiple sclerosis; immunotherapy; drug delivery; vaccine

\section{Introduction}

In the early 1900s, only a few cases of multiple sclerosis (MS) were reported, which quickly became a common occurrence for admission to neurological wards. Today, MS accounts over 2.5 million affected individuals with an estimated cost of US $\$ 2-3$ billion per annum [1]. The distribution of MS varies according to geographic location. For example, the further north or south from the equator the higher the prevalence of MS; countries that lie on the equator have extremely low prevalence compared to Scotland, Norway, and Canada. The prevalence of MS has increased progressively over time with 30/100,000 diagnosed in 2008 to 33/100,000 diagnosed in 2013 globally. In fact, in a Norwegian cohort over 53 years (1961-2014), the prevalence increased from 20 to 203/100,000 and the incidence increased from 1.9 to $8 / 100,000$ [2]. It is possible that the increase in prevalence is due to improved diagnostic procedures and reporting and changes in lifestyle (lack of vitamin D and increased smoking) [1]. MS is commonly diagnosed between 20 years and 40 years of age although it can affect younger and older individuals [3], and most commonly affects those with a genetic predisposition (major histocompatibility complex (MHC) class II phenotype, human leukocyte antigen (HLA)-DR2 and HLA-DR4 most commonly affected). In fact, the incidence of MS is increased 10-fold in monozygotic 
twins as compared to siblings of patients with MS [4-6]. In addition, viral infections can trigger disease where parts of the virus mimics that of the myelin sheath [7]. Although usually not life-shortening, MS is a chronic neurological disease often interfering with life and career plans of an individual [8].

MS is categorized into 4 distinct types, primarily based on its clinical course, which are characterized by increasing severity: (a) Relapsing/remitting MS (RRMS), the most common form, affecting $85 \%$ of all MS patients which involves relapses followed by remission; (b) secondary progressive MS (SPMS), which develops over time following diagnosis of RRMS; (c) primary progressive MS (PPMS) affecting $8-10 \%$ of patients, noted as gradual continuous neurologic deterioration; and (d) progressive relapsing MS (PRMS) the least common form $(<5 \%)$, which is similar to PPMS but with overlapping relapses [9-11]. MS leads to a wide range of symptoms with various severity involving different parts of the body. MS diagnosis is mainly clinically based however, magnetic resonance imaging (MRI) assists in diagnosis [12]. As such, examination of the cerebrospinal fluid (CSF) and visual induced potentials with MRI can assist in confirming the clinical suspicion of MS [12,13]. MS symptoms and disease progression are varied, with some individuals experiencing little disability while most (up to $60 \%$ ) require a wheelchair 20 years from diagnosis [9].

Although treatments against MS are able to decrease the relapse rate in RRMS, the prevention of long-term effects remains a problem; medications for progressive forms of MS are also limited in their efficacy. Hence, new improved drugs are required to effectively treat MS. One of the major pathophysiological mechanisms of MS involves autoreactive $\mathrm{T}$ cells, primarily $\mathrm{T}$ helper (Th)-1 CD4 ${ }^{+} \mathrm{T}$ cells and Th17 cells leading to cytokine secretion and activation of an inflammatory cascade resulting in demyelination within the brain and spinal cord and axonal damage; autoreactive antibodies cannot be discounted. Indeed, MS is generally known as a chronic autoimmune disorder of the central nervous system (CNS) $[14,15]$. MS causes breakdown of the blood brain barrier (BBB) leading to migration of immune cells (macrophages, T cells, B cells) and secretion of pro-inflammatory cytokines and chemokines [16] which induces inflammation, formation of sclerotic plaques (lesions), demyelination and neurodegeneration [17]. MS lesions may form in any location of the CNS white matter or in grey matter, often leading to physical disability and sometimes, decline in cognitive ability $[16,18]$. It is therefore, conceivable to target immune cells and their products in order to prevent tissue damage by modulating inflammation $[9,19]$ while reducing potential side effects such as global immunosuppression $[6,19,20]$. The major constituents of the myelin sheath in which autoreactive $T$ cells and antibodies recognize, include, myelin basic protein (MBP), myelin oligodendrocyte glycoprotein (MOG) and proteolipid protein (PLP).

\section{Immunopathophysiology of MS}

The brain has primarily been considered to be an organ which is highly immune-advantaged, although a number of studies have challenged this [6]. In the last 10 years an important shift has surfaced in MS research, suggesting that MS is not just a disease of the immune system, but equally involves factors contributed by the CNS [21,22]. Immune cells residing in the CNS get activated following damage to CNS tissue; notably microglial cells whereby they upregulate MHC class I and II molecules and cell surface co-stimulatory molecules and secrete cytokines and chemokines, paving entry for T (CD4 and CD8) cells, B cells, monocytes, macrophages and dendritic (DC)-like cells into CNS lesions [6]. Infiltrating immune cells secrete pro-inflammatory cytokines, nitric oxide, and matrix metalloproteinases [23,24], leading to destruction of the myelin sheath.

It has been generally accepted that chronic inflammation is the hallmark of neurodegenerative diseases, such as MS, Alzheimer's disease and Parkinson's disease [6,7]. Myelin-reactive auto-T cells cross the BBB [19] and their migration into the CNS consequently initiates an inflammatory cascade followed by demyelination of the CNS and axonal damage. These cells reside in the perivenous demyelinating lesions which generate distinct inflammatory demyelinated plaques situated within the white matter [25]. MS lesions appear in the white matter inside the visual neuron, basal ganglia, brain stem and spinal cord [26]. White matter cells transmit neural signals from grey matter, where 
information is gathered, and transferred to the rest of the body [25,27]. MS involves 2 main steps, (i) myelin sheath damage resulting in formation of lesions in the CNS and (ii) inflammation, which together destroy the neuron tissue [25,28]. In MS, damage of oligodendrocytes and destruction of myelin sheath leads to breakdown of the nerve axon and loss of neuronal function [28]. Demyelination increases the inflammatory activation processes leading to damage of BBB and stimulation of macrophage activation and oxidative stress pathways [29]. The white matter lesions include myelin breakdown together with infiltration of monocytes, B cells, T cells and DC [30]. Microglia and macrophages are the main innate immune cells present in MS lesions where they either act together with $\mathrm{T}$ and B cells, or directly cause neuroinflammatory tissue damage [31]. Cells involved in the inflammatory process include those that are both in the innate and adaptive immune systems and are described below (Figure 1).

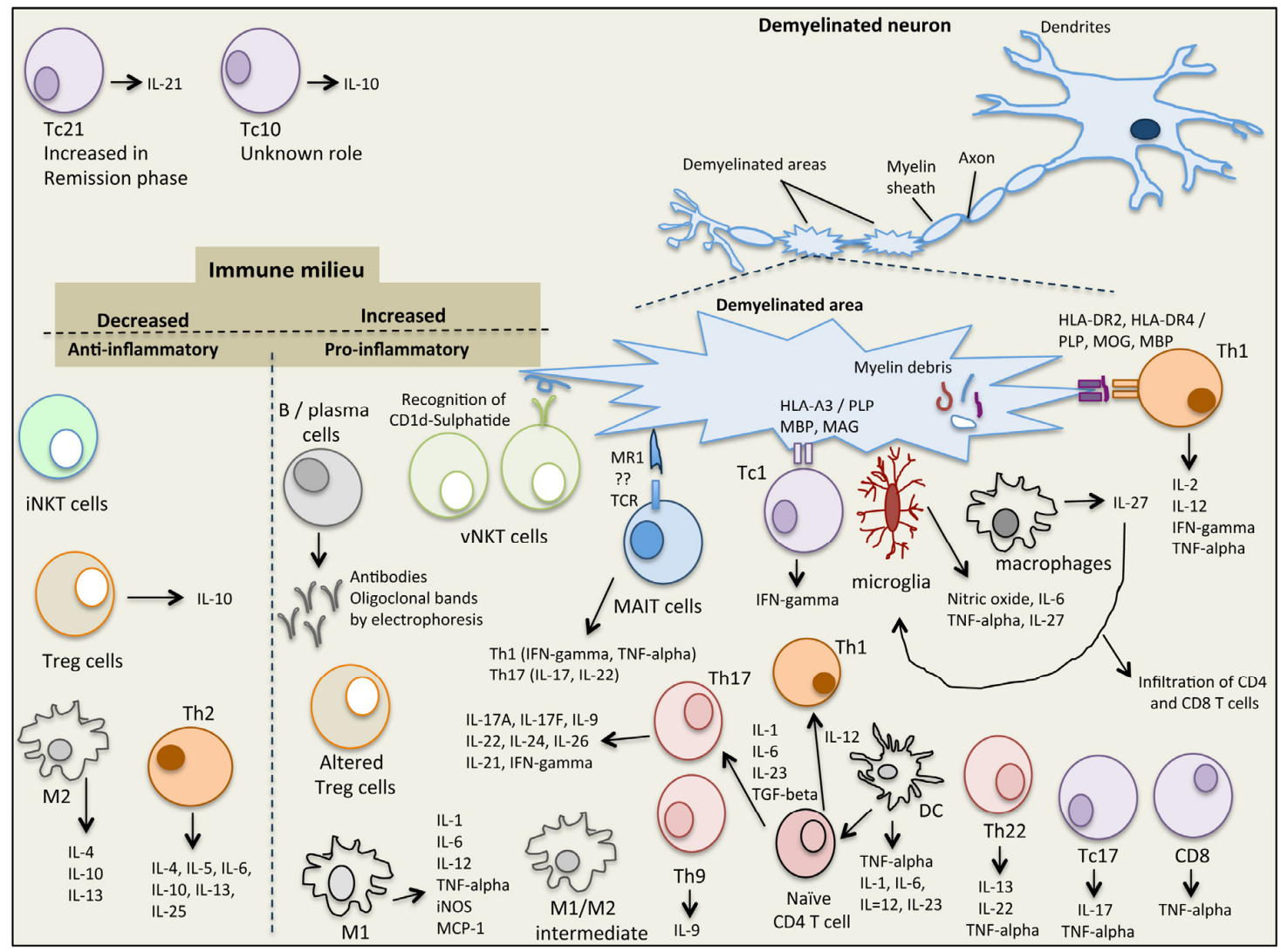

Figure 1. The immunological complexity of the immune/cytokine network in multiple sclerosis.

\subsection{Natural Killer T (NKT) Cells}

NKT cells share properties of both T cells and NK cells and recognize glycolipid antigens presented in complex with the MHC class I-like molecule, CD1d. Two subsets of NKT cells have been identified (type I, invariant NKT (iNKT) cells and type II, variant NKT (vNKT) cells) and are implicated in the pathogenesis of MS in humans and in the murine model of MS, experimental autoimmune encephalomyelitis (EME). iNKT cells express cell surface markers characteristic of activated or memory T cells (CD25, CD44, CD69) with the majority being CD4 ${ }^{+}$as well as markers characteristic of NK cells (NK1.1 or CD161, Ly49). Following activation of iNKT cells (via binding to $\alpha$-GalCer-CD1d complex) an array of cytokines is secreted that are associated with both pro- and anti-inflammatory immune responses and play a role in both innate and acquired immunity. As such, iNKT cells, (i) secrete interleukin (IL)-4 and IL-13 which stimulate CD4 ${ }^{+} \mathrm{T}$ cells to differentiate into anti-inflammatory Th2 cells (IL-4, IL-10 producers) which inhibit Th17, Th1, CD8 ${ }^{+}$T cells in the CNS; (ii) secrete IL-2 
and tumor growth factor (TGF)-beta which stimulate the production of $\mathrm{T}$ regulatory (Treg) cells (IL-10, TGF-beta producers) which inhibit Th17, Th1 and CD8 ${ }^{+} \mathrm{T}$ cells in the CNS; and (iii) secrete IL-4, IL-10, IL-13, interferon (IFN)-gamma and GM-CSF which activate suppressive myeloid derived suppressor cells (MDCs), DC and macrophages which in turn secrete IL-10 to activate Treg cells and suppress Th17, Th1 and CD8 ${ }^{+} \mathrm{T}$ cells in the CNS [32]. Due to the pleiotropic properties of iNKT cells, they play a role in protecting the host against pathogens, tumors, autoimmunity and are involved in tissue rejection, ischemia reperfusion injury and obesity related diabetes [32]; deficiency or dysfunction of iNKT cells has been shown to be linked to the development of autoimmune diseases. Indeed, iNKT cell numbers are decreased in patients with MS [32] and are restored in patients in remission [33]. Analysis of iNKT cells in MS patients in remission showed a Th2 cytokine profile, suggesting an immunoregulatory effect of iNKT cells in MS [34]. Similarly, in the EAE mouse model, protection of EAE development is associated with high levels of iNKT cells and suppression of Th1 and Th17 cells [35]. Interestingly, injections of $\alpha$-Galactosylceramide ( $\alpha$-GalCer), and analogues thereof, have potent activities in protecting mice against, cancer, infections, inflammatory conditions and autoimmune disorders. Hence, it is possible to develop iNKT cell based modulating therapies against MS [36,37]. Like iNKT cells, variant NKT (vNKT) cells also share properties of both T cells $\left(\mathrm{CD}^{+}\right)$and NK cells (NK1.1) and recognize $\beta$-linked glycolipid antigens in complex with CD1d. They are less common in mice compared to iNKT cells but are more abundant in humans. Of interest, vNKT cells recognize the self-glycolipid, sulphatide, which is abundantly expressed within the myelin sheath suggesting a role in MS although not yet established [38]. Likewise, vNKT cells recognizing sulphatide self-myelin ligand are present in high levels in mice with EAE suggesting their role in disease progression [38].

\subsection{Mucosal-Associated Invariant T (MAIT) Cells}

MAIT cells are a subset of $\mathrm{T}$ cells of the innate immune system to defend against microbial infections. They are present in the liver, lungs, mucosa and blood and make up to $25 \%$ of CD8 $\mathrm{T}$ cells in healthy individuals; they also support adaptive immune responses in that they have a memory like phenotype [39]. The MHC class I-like molecule, MRI, presents microbial antigens and vitamin B metabolites to MAIT cells, leading to their activation [39,40]. However, MAIT cells have also been implicated in autoimmune diseases such as MS, inflammatory bowel disease and rheumatoid arthritis where they are often noted at the site of autoimmune attack. Recently, it was reported that in MS, MAIT cells are highly present at the sites of demyelination and secrete pro-inflammatory Th1 cytokines (IFN-gamma and TNF-alpha) and activate Th17 cells (IL-17 and IL-22 cytokines) [22]; the major cytokines in the pathogenesis of chronic inflammatory and autoimmune diseases. In addition, MAIT cell have been noted in white matter inflammatory lesions [41] as well as transcription over expression of MR1 in MS lesions. Conversely, it has been reported that MAIT cells are decreased in blood of patients with RRMS [42]. It is not clear whether MAIT cells exert a protective or a non-protective role, thus a better understanding of how MAIT cells are involved in MS and of their interactions would aid in a better understanding of the pathogenesis of MS and development of therapeutic strategies.

\subsection{Regulatory T Cells (Tregs)}

Regulatory T cells (Tregs; originally known as suppressor $\mathrm{T}$ cells) are a subset of $\mathrm{CD} 4^{+} \mathrm{T}$ cells that modulate immunity, maintain tolerance against self-antigens and prevent autoimmunity. Tregs are primarily characterized as Foxp $3^{+} \mathrm{CD} 25^{+} \mathrm{CD} 4^{+}$and are anti-inflammatory (secrete IL-10). One of the first evidence of the role of Treg cells in MS was in mouse EAE models, where adoptive transfer of Treg cells from control mice into MOG or PLP induced EAE mice prevented the onset and progression of EAE $[43,44]$. Adoptive transfer of Treg cells recovering from EAE into MOG-induced active EAE mice resulted in resolution of EAE [45]. In addition, induction of Treg cells by estradiol or by monocytes under glatiramer acetate treatment reduced clinical signs of MOG-EAE [46,47]. Furthermore, injection 
anti-CD28 monoclonal antibody in Lewis rats results in Treg cell expansion and reduction in EAE disease severity [48]. Interestingly, injection of anti-CD25 monoclonal antibody, which blocks the effects of Treg cells into C57BL/ 6 mice increased susceptibility to EAE induction [45]. In patients with MS however, the frequency of Foxp $3^{+} \mathrm{CD} 25^{+} \mathrm{CD} 4^{+}$Treg cells does not differ to those in healthy individuals, although the function of such cells are impaired (maturation and migration) [49]. In addition, mRNA and protein levels of Foxp3 are impaired in Treg cells of patients with MS especially in RRMS and are normalized during SPMS [49]. Hence, impaired functionality of Treg cells is primarily observed in the early stages of MS but not in their chronic stage, suggesting a causative role [50]. Further studies of Treg cells in MS may aid in the understanding for why tolerance against self-antigens is broken, leading to disease. However, it is not clear whether the impaired function of Treg cells is a direct cause of MS or whether such impairment is a general outcome for all autoimmune disorders.

\subsection{Macrophages and Microglia}

Macrophages are divided into M1 or M2 based on their pro- or anti-inflammatory cytokine secretion phenotype [51]. M1 macrophage phenotype of mice $\left(\mathrm{F} 4 / 80^{+} \mathrm{CD} 11 \mathrm{~b}^{+} \mathrm{CD} 11 \mathrm{c}^{+} \mathrm{iNOS}^{+}\right)$ and human $\left(\mathrm{CD} 40^{+} \mathrm{CD} 86^{+} \mathrm{CD} 64^{+} \mathrm{CD} 32^{+}\right)$is induced in the presence of interferon (IFN)-gamma and/or toll-like receptor (TLR) ligands such as lipopolysaccharide (LPS). M1 macrophages are pro-inflammatory and primarily secrete IL-1, IL-6, IL-12, TNF-alpha, iNOS and MCP-1 [51]. In general, they stimulate adaptive immune responses. The $\mathrm{M} 2$ macrophage phenotype of mice $\left(\mathrm{F} 4 / 80^{+} \mathrm{CD} 11 \mathrm{c}^{-} \mathrm{CD} 301^{+} \mathrm{Arg} 1^{+} \mathrm{CD} 206^{+}\right)$and humans $\left(\mathrm{CD} 163^{+} \mathrm{CD}^{2} 06^{+}\right)$is induced in the presence of IL-4, IL-10, IL-13 and Arg1 that blocks iNOS activity [51]. M2 macrophages are anti-inflammatory and primarily secrete IL-1 receptor antagonist, IL-4, IL-10, transforming growth factor (TGF)-beta1. Macrophages play a crucial role in the pathogenesis of MS. In fact, in active demyelinating and early re-myelinating lesions, macrophages are highly present compared to inactive, demyelinated or late re-myelinated lesions [52]. However, a distinction of M1 vs M2 macrophages in human brain tissues is not so clear, with both M1 macrophages and an intermediate subtype (M1/M2, CD40 ${ }^{+} \mathrm{CD} 206^{+}$) being present [53]. Like macrophages, microglia cells are divided into M1- and M2-polarized microglia cells. M1 microglia cells are pro-inflammatory and express CD40, CD74, CD86 and CCR7, whereas, M2 microglia cells are anti-inflammatory and express mannose receptor (CD206) and CCL22. In MS brain lesions however, like macrophages, an intermediate microglia phenotype is present expressing CD40, CD74, CD86 and CCL22 but not CD206 markers [54]. Interestingly, in an EAE model it was shown that suppression of CCL22 decreased M1 macrophage accumulation in the CNS, thus therapies designed to suppress CCL22 have the potential to decrease demyelination and progression of disease. In addition, in mice M1 microglia cells have been found to switch to M2 microglia cells during remyelination, hence M2 polarization is necessary for efficient remyelination [55]. Indeed, fasudil (a selective Rho kinase inhibitor), injected into EAE bearing mice shifted M1 to M2 macrophages and ameliorated the clinical severity of EAE [56].

\section{5. $T$ Helper Cells}

CD4 T cells or T helper (Th) cells, recognize short 9-17 amino acid peptides presented on the surface of antigen presenting cells (APC) in complex with MHC class II. CD4 T cells differentiate into distinct Th cells depending on the cytokine secretion profiles [57]. (i) Th1 cells are pro-inflammatory and produce high levels of IL-2, IL-12, TNF-alpha and IFN-gamma; (ii) Th2 cells are anti-inflammatory and secrete IL-4, IL-5, IL-6, IL-10, IL-13, IL-25; (iii) Th17 cells are pro-inflammatory and secrete high levels of IL-17A, IL-17F, IL-21, IL-22, IL-24, IL-26 and low levels of IL-9 and IFN-gamma; (iv) Th22 cells which are a combination of Th1, Th2, Th17 phenotype and secrete IL-13, IL-22 and TNF-alpha and (v) the newest addition to the Th subset, Th9, was identified for its potent secretion of IL-9. Th1, Th9, Th17 cells are key contributors to MS by increasing inflammation within the milieu of the myelin site.

Th1 cells and their pro-inflammatory cytokine products are present in high levels within the demyelinating axon and CNS lesions of humans and in MOG, PLP or MBP induced EAE in mice. 
Th1 cells recognize MOG, PLP and MBP peptide epitopes presented in the context of MHC class II, HLA-DRB1*1501 (HLA-DR2, HLA-DR15) and HLA-DRB1*04 (HLA-DR4) alleles. As a result CD4 $\mathrm{T}$ cells become activated, cross the blood brain barrier and induce CNS autoimmunity. Some drug therapeutics target the MHC class II-peptide-T cell receptor (TCR) complex in an attempt to modulate or divert Th1 responses to therapeutic Th2 responses. Indeed, it was recently shown that dimethyl fumarate (DMF) injection in RRMS patients reduced Th1, Th17 and CD8 T cells and increased Th2 cells; this resulted in high levels of IL-4 and decreased levels of IFN-gamma and IL-17 [58]. In addition, we have shown that mannan conjugation of self-MBP, PLP or MOG native peptides or altered peptide ligands, are able to divert Th1 responses to Th2 responses in human PBMC from MS patients, in immunized mouse spleen cells and are able to ameliorate EAE in mice [59-73]. The role of Th9 cells in MS is not as clear although in mice, IL-9 and Th9 cells induce EAE and inflammation and IL-9 knockout mice are protected from developing EAE [74]. Th17 cells play a crucial role in the pathogenesis of MS in both mice and humans by inducing an inflammatory milieu. In fact, IL-17A is present at high levels in CNS lesions, cerebrospinal fluid and in the serum of patients with MS [75]. Th17 cells express high levels of CCR6 which binds to the ligand CCL20 on vascular endothelial cells, enabling their entry through the blood brain barrier where they secrete pro-inflammatory cytokines including IL-17A. In addition, IL-17 interferes with the remyelination process. Of interest, anti-IL-17A humanized neutralizing monoclonal antibody (AIN457 or Secukinumab) injected in patients with MS showed reduction of lesions compared to placebo-treated control subjects [75]. In addition, Th22 cells are highly present in the peripheral blood and cerebral spinal fluid of patients with active RRMS [76], and IL-22 mRNA and Th22 cells are increased in relapsing MS compared to remitting MS patients [77]. Furthermore, Th22 cells specifically recognize MBP and are resistant to IFN-beta therapy [76].

IL-27, a member of the IL-6/IL-12 cytokine family, is secreted by macrophages, dendritic cells and microglia cells, with pleiotropic roles in immunomodulation being either pro- or anti-inflammatory. IL-27 also stimulates or inhibits T cell differentiation. Th1 cells are induced by IL-27 whereas Th2, Th17 and Treg cells are inhibited by IL-27. In addition, Tr1 cells a specialized subset of T cells which secrete IL-10 are induced in the presence of IL-27 [78]. In 40 patients with RRMS, circulating plasma IL-27 levels were significantly higher compared to healthy control subjects [79]. Likewise, IL-27 and IL-27R are elevated in post-mortem MS brain lesions compared to non-MS control brains. Macrophages and microglia were identified to be the source of IL-27 and triggering infiltration of CD4 and CD8 T cells [80]. In addition, the effects of IL-27 on microglia cells showed that nitric oxide, TNF-alpha and IL-6 were secreted, promoting Th1 polarization, suggestive that IL-27 enhances microglia neuroinflammation [81]. Hence, suppressing IL-27 may be a strategy to modulate inflammatory responses in patients with MS.

\subsection{CD8 T Cells}

Classical CD8 $\mathrm{T}$ cells or cytotoxic T cells (Tc1 cells), recognize short antigenic 7-9-mer peptide epitopes presented on the surface of APC in complex with MHC class I. In MS there is a genetic association with HLA-A3 [82]; HLA-A2 has been shown to reduce the risk of MS in individuals that also express MHC class II, HLA-DRB1*1501. The antigen specificity of CD8 Tc1 cells isolated from patients with MS, has been suggested to be against MOG, MBP and PLP with cytolytic activity against neuronal cells in vitro [83] although their pathogenic role in MS is still not clear. More recently other subsets of CD8 T cells have been identified and are grouped into different subsets based on their cytokine profile. In as such, classical Tc1 cells secrete IFN-gamma, Tc2 secrete IL-4, Tc10 secrete IL-10, Tc17 secrete IL-17, Tc21 secrete IL-21, Tc22 secrete IL-22 and another subset is characterized by secreting TNF-alpha. In MS, regardless of the stage and activity of disease CD8 T cells are noted in high numbers, much higher than CD4 T cells at a ratio of 10:1 CD8:CD4 T cells. MHC class I is highly expressed within MS lesions and astrocytes, oligodendrocytes, neurons in addition to the classical APC, DCs and macrophages. In fact, CD8 T cells are found in great abundance within CNS tissues and cerebrospinal fluid of patients with MS. CD8 T cells present in both acute and chronic 
MS lesions secrete high levels of IL-17 (classed as, Tc17 CD8 T cells) [84]. Tc17 cells secrete IL-17 and TNF-alpha and low IFN-gamma and are negative for granzyme B, perforin and cytolytic activity unlike the classical CD8 Tc1 cells. In peripheral blood of patients with SPMS and RRMS elevated levels of Tc1 and Tc17 cells are noted as well as a high percentage of TNF-alpha secreting CD8 T cells [85]; Tc21 cells are increased in the remission phase of RRMS compared to SPMS. In addition, higher levels of $\mathrm{CD}^{+} \mathrm{IFN}$-gamma ${ }^{+} \mathrm{TNF}-\mathrm{alpha}{ }^{+} \mathrm{IL}-17^{+} \mathrm{T}$ cells in the relapsing phase of RRMS compared to remission phase, SPMS and controls [85]. It is clear that CD8 T cells contribute to the pathogenesis of MS, and it is important to understand how such cells escape T cell tolerance and induce CNS autoimmunity in order to design and develop new therapeutics against MS.

\subsection{B Cells}

Although there is a presence of T cells in MS plaques, B cells also contribute to the pathogenesis of MS where they secrete autoantibodies and cytokines and being APC they activate T cells. In patients with MS the presence of oligoclonal bands (OCB) in cerebrospinal fluid and brain parenchyma is a consistent finding in over $95 \%$ of patients. OCB is a product of clonally expanded B cells and IgG synthesis. In MS plaques plasma cells are noted in large numbers where antigen uptake, processing and presentation takes place as well as synthesis of IgG. Interestingly, over 50 antibodies isolated from cerebrospinal fluid from patients with MS did not react to MBP, PLP or MOG [86] but some groups reporting that they bind to intracellular proteins such as, MKNK1/2, FAM84A, AKAP12A and glial potassium channel KIR4.1, or, against intracellular lipid determinants [87,88]. Moreover, anti-MOG autoantibodies is a hallmark of childhood MS as well as in some patients with neuromyelitis optical spectrum disorder. It is clear, that abnormal activation of B cells within the CNS of patients with MS, suggests that B cells play a role in the pathophysiology of the disease. Further studies are required to ascertain whether $B$ cell depletion is able to restore immune function and hence, be used as a therapeutic target against MS.

\subsection{Dendritic Cells}

DC are professional APC which process and present antigenic peptide epitopes on their surface in complex with MHC class I or class II, resulting in CD4 or CD8 T cell stimulation respectively. Even though MS is generally associated with predominant auto-reactive T cells, emerging evidence indicates that DCs play an important role in the pathophysiology of MS, primarily due to their T cell activating and cytokine secreting properties. Following activation of DCs in the periphery, T cells specific to myelin epitopes are activated inducing pro-inflammatory cytokines aiding their entry through the BBB into the CNS. In the CNS resident APC and T cells are further activated leading to demyelination and motor deficits. In patients with MS, DCs are abundantly present within inflamed lesions, cerebrospinal fluid and in the circulation and produce high levels of TNF-alpha, IFN-gamma and IL-6 [89]. In addition, the expression of co-stimulatory molecules, CD40 and CD80 on DCs are increased in RRMS and SPMS patients, suggesting an activated pro-inflammatory state of DCs, hence their contributing role in the pathogenesis of MS.

\subsection{Myeloid Derived Suppressor Cells}

Myeloid-derived suppressor cells (MDSC) are myeloid progenitors, the same lineage to that of macrophages, DC and neutrophils. However, MDSC have strong immunosuppressive properties rather than immune-stimulatory properties as noted with macrophages, DC and neutrophils [90]. Their major role is in tumor development and chronic inflammation having immune suppressive effects [90]. As such, it was recently shown following $\mathrm{MBP}_{1-11}$ peptide immunization in mice, that MDSCs were increased adopting a suppressive phenotype, inhibiting the activation of $\mathrm{CD} 4^{+} \mathrm{T}$ cells via arginase- 1 and inducible nitric oxide synthase; such approach inhibited the development of EAE in mice [91]. In addition, MDSC secrete inhibitory enzyme indoleamine 2,3-dioxygenase and Th2 cytokine, IL-10 [92]. It is not clear whether the number of MDSCs are reduced or whether their functionality is altered 
in patients with MS, leading to the failure of MDSCs to suppress autoimmune T cells, as a result of disease progression. The use of ex vivo cultured MDSCs could be a viable strategy to develop new improved treatments against MS.

\section{Current Drug Therapies for Multiple Sclerosis}

The majority of the treatments for MS are long term mainly suppressing the immune system however, such immune-suppressants pose increased risks for infections and cancer [27]. Alternative treatment options involve disease-modifying therapies such as, interferons, glatiramer acetate, monoclonal antibodies and sphingosine-1-phosphate receptor modulators (Table 1, Figure 2). These therapies have dramatically reduced the number of attacks and decreased disease progression. In fact, interferons are effective in the early relapsing phases of MS but not in the advanced phases of the disease [27]. Ultimately, induction of tolerance against self-antigens and re-establishing immune homeostasis can effectively "cure" the disease; such strategies have been the focus of recent research.

Table 1. Disease-modifying drugs available to patients with RRMS.

\begin{tabular}{|c|c|c|c|c|}
\hline Drug & Brand & Dose & $\begin{array}{c}\text { Number of of } \\
\text { Injections, Route }\end{array}$ & Actions \\
\hline \multirow{4}{*}{ IFN- $\beta 1 \mathrm{a}$} & \multirow{3}{*}{ Avonex $^{\circledR}$} & $7.5 \mathrm{mg}$ 1st dose & \multirow{3}{*}{ 1/week, i.m } & $\begin{array}{c}\text { Balances pro- and } \\
\text { anti-inflammatory cytokines }\end{array}$ \\
\hline & & $15 \mathrm{mg}$ 2nd dose & & Decreases Th17 cells \\
\hline & & $22.5 \mathrm{mg} 3 \mathrm{rd}$ dose & & Decreases IL-17 \\
\hline & Rebif $^{\circledR}$ & $22 \mathrm{mg}$ or $44 \mathrm{mg}$ & 3/week, s.c & \\
\hline \multirow[t]{2}{*}{ IFN- $\beta 1 b$} & Betaseron $^{\circledR}$ & $\begin{array}{l}62.5 \mathrm{mg} \text { and increase over } \\
6 \text { weeks to } 250 \mathrm{mg}\end{array}$ & $1 / 2$ days, s.c & \\
\hline & Extavia $^{\circledR}$ & $\begin{array}{l}62.5 \mathrm{mg} \text { and increase over } \\
6 \text { weeks to } 250 \mathrm{mg}\end{array}$ & $1 / 2$ days, s.c & \\
\hline pegIFN- $\beta 1 \mathrm{a}$ & Plegridy ${ }^{\circledR}$ & $\begin{array}{c}63 \mathrm{mg} \text { 1st dose } \\
95 \mathrm{mg} \text { 2nd dose } \\
125 \mathrm{mg} \text { all subsequent doses }\end{array}$ & $1 / 2$ weeks, s.c & \\
\hline $\begin{array}{l}\text { Glatiramer acetate, } \\
\text { EKAY }\end{array}$ & Copaxone $^{\circledR}$ & $20 \mathrm{mg}$ or $40 \mathrm{mg}$ & $\begin{array}{l}\text { 1/day, s.c } \\
\text { 3/week, s.c }\end{array}$ & Blocks pMHC \\
\hline Dimethyl fumarate & Tecfidera $^{\circledR}$ & $240 \mathrm{mg}$ & 2-3/day, oral & Anti-inflammatory Anti-oxidative stress \\
\hline Teriflunomide & Aubagio $^{\circledR}$ & 7 or $14 \mathrm{mg}$ & $1 /$ day, oral & $\begin{array}{c}\text { Inhibits dihydroorotate dehydrogenase, } \mathrm{T} \text {, } \\
\mathrm{B} \text { cells and IFN- } \gamma \text { secreting T cells }\end{array}$ \\
\hline Fingolimod & Glenya $^{\circledR}$ & $0.5 \mathrm{mg}$ & $1 /$ day, oral & $\begin{array}{l}\text { Antagonist of SIP receptor Decrease T, } \\
\text { B cells activates SIP signaling in CNS }\end{array}$ \\
\hline Mitoxantrone & Novatrone ${ }^{\circledR}$ & $12 \mathrm{mg} / \mathrm{m}^{2}$ & $\begin{array}{l}1 / 3 \text { months up to } \\
2 \text { years }\end{array}$ & $\begin{array}{l}\text { Suppresses T, B cells and macrophages. } \\
\text { Reduces Th1 cytokines }\end{array}$ \\
\hline Dalfampridine & Ampyra $^{\circledR}$ & $10 \mathrm{mg}$ & $2 /$ day, oral & $\begin{array}{l}\text { Potassium channel blocker Improves } \\
\text { motor symptoms, i.e., walking }\end{array}$ \\
\hline \multicolumn{5}{|c|}{ Humanized Monoclonal Antibody Treatments } \\
\hline Natalizumab & Tysabr $^{\circledR}$ & $300 \mathrm{mg}$ & $1 / 28$ days, i.v & $\begin{array}{c}\text { Humanized anti- } \alpha 4 \text {-integrin Mab. Affects } \\
\text { cell migration, division, growth } \\
\text { and survival }\end{array}$ \\
\hline Ofatumumab & Arzerra $^{\circledR}$ & 3-700 mg & $1 / 2$ weeks, i.v & $\begin{array}{l}\text { Humanized anti-CD20 Mab. Cytotoxic to } \\
\text { CD20+ cells via CDC and ADCC }\end{array}$ \\
\hline Ocrelizumab & Ocrevus $^{\circledR}$ & $300-600 \mathrm{mg}$ & $\begin{array}{l}300 \mathrm{mg} \text { weeks } 1 \\
\text { and } 3 \text {, then } 600 \mathrm{mg} \\
1 / 6 \text { months, i.v }\end{array}$ & Humanized anti-CD20 Mab \\
\hline Alemtuzumab & Lemtrada ${ }^{\circledR}$ & $12 \mathrm{mg}$ & $\begin{array}{l}5 \text { days in a row; } \\
\text { after } 1 \text { year, } 3 \text { days }\end{array}$ & $\begin{array}{c}\text { Humanized anti-CD52 Mab. Depletes T, } \\
\text { B cells, increases Treg, Th2, decrease } \\
\text { Th1 cells }\end{array}$ \\
\hline Daclizumab & Zinbryta ${ }^{\circledR}$ & $150 \mathrm{mg}$ & $1 /$ month, s.c & $\begin{array}{l}\text { Humanized anti-CD25 Mab.Blocks IL-2R, } \\
\text { decreases T cells, increases NK cells }\end{array}$ \\
\hline
\end{tabular}

ADCC, antibody-dependent cellular cytotoxicity; CDC, complement-dependent cytotoxicity; DC, dendritic cells; EKAY, single amino acid code for L-glutamic acid, lysine, alanine, tyrosine; IFN, interferon; IL-2R, interleukin-2 receptor; i.m, intramuscular; i.v, intravenous; Mab, monoclonal antibodies; NK, natural killer cells; pegIFN, polyethylene glycol linked to IFN; pMHC, peptide-major histocompatibility complex; RRMS, relapsing remitting multiple sclerosis; s.c, subcutaneous; SIP, sphingosine-1-phosphate; Th, helper T cells; Treg, regulatory T cells $\left(\mathrm{CD} 4^{+} \mathrm{CD} 25^{+} \mathrm{FoxP}^{+}\right)$. 


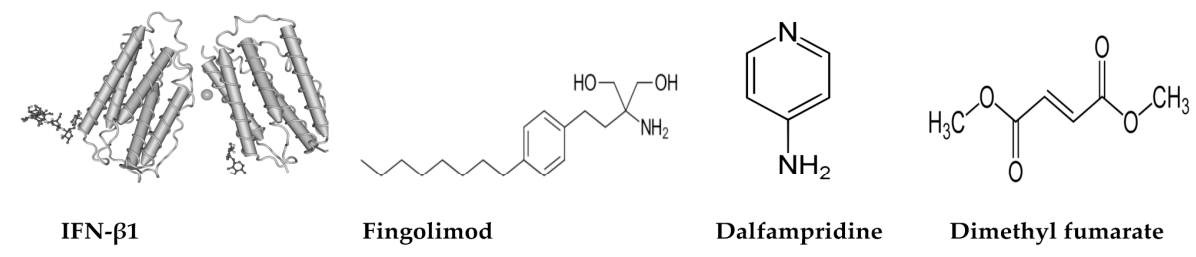

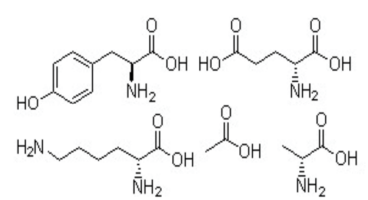

Gatiramer Acetate

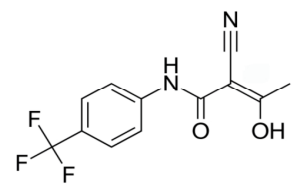

Teriflunomide

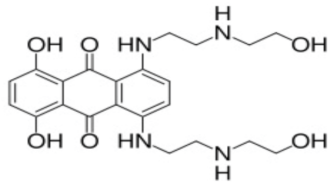

Mitoxantrone

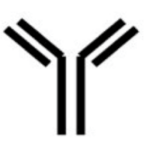

Natalizumab

anti- $\alpha 4$ integrin

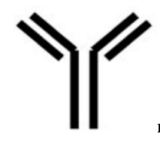

Ofatumumab Ocrelizumab

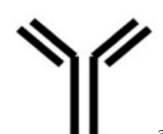

Alemtuzumab

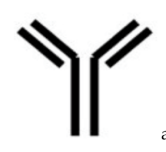

Daclizumab

Figure 2. Chemical/schematic structures of treatments/drugs for MS.

\subsection{Treatment of MS Relapses}

Patients with MS who present with a relapse are generally treated with corticosteroids intravenously, plasma exchange or adrenocorticotropic hormone injections [50,93]. Although effective in reducing the duration of the relapse and patients recovery faster there are no long-term neuroprotective benefits [27,94-97].

\subsection{Long-Term Treatment of MS with Disease-Modifying Agents}

The treatment of MS has been a challenge with treatment options being limited mainly to corticosteroids, the potent alkylating agent cyclophosphamide and potent immunosuppressant methotrexate (Table 1, Figure 2). However, with the advent of immunomodulatory drugs in mid-1990s, a big shift was carried to treatment options for the first time [50]. The first disease-modifying drug for RRMS, interferon beta-1(IFN $\beta-1$ ) was the primary key breakthrough for the treatment of MS [98,99]. Disease-modifying agents intend to modify the course of the disease rather than improving symptoms.

Until the approval of the first oral treatment in 2010 [11], all MS treatments consisted of either intramuscular or subcutaneous injectable drugs. To date, 13 FDA approved disease-modifying drugs are available for RRMS, and several more agents are in different developmental stages $[9,11,65,66,69]$. In the last 20 years there has been an evolving trend in novel treatments for MS and the global progress of therapies for MS has been quite promising. In general treatments consist of Ampyra ${ }^{\circledR}$, Aubagio $^{\circledR}$, Avonex $^{\circledR}$, Betaseron ${ }^{\circledR}$, Copaxone $^{\circledR}$, Extavia $^{\circledR}$, Gilenya $^{\circledR}$, Lemtrada $^{\circledR}$, Novantrone $^{\circledR}$, Plegridy $^{\circledR}$, Rebif ${ }^{\circledR}$, Tecfidera ${ }^{\circledR}$ and Tysabri ${ }^{\circledR}[100]$. Such treatment options consist of alemtuzumab (depletes lymphocytes), daclizumab (blocks the cytokine receptor IL-2), dimethylfumarate (combines features of immunomodulatory and immunosuppressive actions), fingolimod (modulates the sphingosine-receptor system), natalizumab (inhibits the migration of lymphocytes) and teriflunomide (inhibits activated $\mathrm{T}$ and $\mathrm{B}$ cells) $[9,27,50]$. Examples of current interferons include, Schering AG's Betaferon/Betaseron (IFN $\beta-1 b)$, Biogen's Avonex (IFN $\beta-1 a)$ and Serono/Pfizer's Rebif (IFN $\beta-1 a)$. In addition, immune modulating agents include, Teva's Copaxone ${ }^{\circledR}$ (copolymer glatiramer acetate), Amgen/Serono's (Novantrone ${ }^{\circledR}$; mitoxantrone), azathioprine, cyclophosphamide (Endoxan ${ }^{\circledR}$ ) and Natalizumab ${ }^{\circledR}$ an $a_{4}$-integrin antagonist [101-103]. Disease-modifying agents have commonly been shown to reduce the rate of relapses, reduce MRI lesions and stabilize or delay MS disability. 
The key therapeutic features of disease-modifying drugs are their anti-inflammatory effects in the relapsing phase of MS, although demyelination leading to chronic disability still remains a major hurdle [27,104-106]. Some studies, however, have shown that early intervention of disease-modifying drugs to patients with RRMS can reduce acute disability or death [27,107-110].

In general, disease-modifying drugs main action is by suppressing or altering the immune system. Hence, based on this theory that MS is, at least in part, a result of altered or abnormal immune response that results in attack of the myelin sheath. Current available drugs and their actions are described below (Table 1, Figure 2).

3.2.1. Interferons (Avonex ${ }^{\circledR}$, Biogen, Cambridge, MA, USA; Betaseron ${ }^{\circledR}$, Bayer, Leverkusen, Germany; Extavia $^{\circledR}$, Novartis Pharma AG, Basel, Switzerland; Rebif ${ }^{\circledR}$, EMD Serono Inc., Darmstadt, Germany; Plegridy ${ }^{\circledR}$, Biogen, Cambridge, MA, USA)

Interferon (IFN) type 1 consist of a group of IFNs (IFN- $\alpha,-\beta,-\varepsilon,-\kappa,-\tau,-\delta,-\zeta,-\omega,-v)$ which help regulate the immune system. IFN- $\beta$ is primarily produced by fibroblasts but other cells such as NK cells, B cells, T cells, macrophages also secrete IFN- $\beta$. IFN- $\beta$ has anti-viral and anti-tumor activity as well as being effective in reducing the relapse rate in patients with MS [106]. The mechanism by which IFN- $\beta$ acts, is that it balances the expression of pro- and anti-inflammatory cytokines in the brain and decreases the number of inflammatory cells crossing the blood brain barrier. As a consequence, there is decreased inflammation of neurons, increases nerve growth factors and improves neuronal survival. Moreover, IFN- $\beta$ reduces Th17 population and IL-17 cytokine which are known to be involved in the immunopathophysiology of MS [111]. IFN- $\beta$ injection subcutaneously or intramuscularly to patients with RRMS aims to decrease the relapse rate, duration and severity, however, there is lack of efficacy to long-term disability. Avonex was approved in 1996, the first FDA approved treatment for RRMS. To date there are 3 approaches using IFN- $\beta$; IFN- $\beta 1$ a low dosage (Avonex $\left.{ }^{\circledR}\right)$, IFN- $\beta 1$ a $\left(\right.$ Rebif $\left.^{\circledR}\right)$ high dosage, and, IFN- $\beta 1 \mathrm{~b}$ (Betaseron ${ }^{\circledR}$, Extavia ${ }^{\circledR}$ ) high dosage. Furthermore, pegIFN- $\beta$-1a (Plegridy ${ }^{\circledR}$ ) has polyethylene glycol linked to IFN- $\beta$-1a allowing it to be active for longer in the body, hence fewer injections are required compared to Avone ${ }^{\circledR}, \operatorname{Rebif}^{\circledR}$, Betaseron $^{\circledR}$ and Extavia ${ }^{\circledR}$. The first large scale human clinical trial in patients with RRMS using IFN- $\beta$ was published in 1993 and showed that relapse rates were reduced by $34 \%$ in high dose IFN- $\beta 1 \mathrm{~b}$ and by $8 \%$ in lower dose compared to placebo group and severity of relapses were also reduced [112]. Subsequent 5 year follow-up data showed that IFN- $\beta 1 \mathrm{a}$ and IFN- $\beta 1 \mathrm{~b}$ decreased lesions up to $30 \%$ and reduced the formation of new lesions up to $50 \%$, however, the study failed to show any reduction in disability progression in patients [113]. IFNs have no direct neuroprotective effects, however, through their direct effect on CD4 ${ }^{+} \mathrm{Th} 1$ cells and altering their profile results in decreased demyelination of neurons, which prevents further neuronal damage [114]. Despite the impact of IFN- $\beta$ in disease progression in patients with RRMS there are limitations in their use, with side effects ranging from local body aches, skin reactions (swelling, redness), fever, myalgia, flu-like symptoms to more serious side effects such as suicidal thoughts, hallucinations, seizures and heart and liver problems [9]. As a result, many patients have stopped treatment and overall the benefit of using IFNs is relatively small.

\subsubsection{Glatiramer Acetate (Copaxone ${ }^{\circledR}$, Inc., Petah Tikva, Israel)}

Glatiramer acetate (GA) is a synthetic 4-mer peptide (L-glutamic acid, lysine, alanine, and tyrosine) mimic of MBP, which competes with short antigenic MBP peptides in complex with MHC class II. Initially, GA was designed to induce EAE but instead it suppressed EAE, which was quickly translated into human trials with MS in order to prevent disease progression, as it bound to MHC class II and inhibited the activation of encephalitogenic T cells [115-118]. GA diverts Th1 cells to Th2 cells that suppress inflammatory responses and activate Tregs in the periphery [119]. In patients, GA significantly reduced disease symptoms and development of new lesions by up to $30 \%$ in RRMS, although it showed no improvement in long-term efficacy on progression of disability [120]. GA injection in patients 
results in side effects ranging from minor (fever, chills) to more serious (cardiovascular, digestive, muscular, respiratory issues).

\subsubsection{Dimethyl Fumarate (Tecfidera ${ }^{\circledR}$, Biogen, Cambridge, MA, USA)}

Dimethyl fumarate (BG-12) is a methyl ester of fumaric acid that modulates immune responses and was approved by the FDA in 2013. BG-12 was shown in phase III clinical trials to reduce relapse rate and increase the time to disability progression in patients with RRMS [121]. BG-12 reduces the migration of inflammatory cells through the blood brain barrier and activates nuclear factor erythroid 2-related factor (Nrf2) [122]. Nrf2 regulates anti-oxidative proteins that protect cells against oxidative damage and inflammation. In fact, BG-12 protects neuronal cells from oxidative stress by increasing glutathione levels and suppressing pro-inflammatory cytokines from splenocytes in vitro [123]. Side effects of BG-12 include diarrhea, abdominal pain, nausea, abnormal liver enzymes and decreased lymphocyte counts.

\subsubsection{Teriflunomide (Aubagio ${ }^{\circledR}$, Sanofi Genzyme, Cambridge, MA, USA)}

Teriflunomide is an active metabolite of leflunomide (an immunosuppressive disease-modifying drug used for rheumatoid arthritis) which inhibits the enzyme dihydroorotate dehydrogenase [124] and inhibits the proliferation of $B$ and $T$ cells. In addition, teriflunomide exerts anti-inflammatory properties by inhibiting IFN-gamma producing T cells while IL-4 and IL-10 producing T cells are unaffected [125]. In MS, oral administration of teriflunomide reduced relapse rates, MS lesions and decreased disability progression [126-131]. Moreover, permanent discontinuation due to side effects was substantially less common in MS patients who received teriflunomide compared to IFN- $\beta$ - 1 a. Side effects include, reduced white blood cell count, alopecia, hepatic effects, nausea, diarrhea, numbness in hand and feet, allergic reactions, breathing issues and increased blood pressure. Teriflunomide was approved by the FDA in 2012 and by EMA in 2013 for use in patients with RRMS.

\subsubsection{Fingolimod (Gilenya ${ }^{\circledR}$, FTY720, Novartis Pharma AG, Basel, Switzerland)}

Fingolimod was granted FDA approval in 2010 and was the first oral therapy ( $0.5 \mathrm{mg}$ once daily) available for patients with relapsing forms of MS. Fingolimod is a sphingosine 1-phosphate (S1P) receptor modulator, which acts as a super agonist of S1P receptor causing receptor internalization and leading to reduced infiltration of potentially auto-reactive lymphocytes into the CNS, and as such, they remain localized in the lymph nodes [132-134]. In addition, a secondary beneficial effects of fingolimod is that it targets SIP receptors on glia cells in the CNS, activating signaling pathways within the CNS [132,135]. Based on Phase III human clinical trials in patients with RRMS (TRANSFORMS, FREEDOMS and FREEDOMS II), fingolimod was more effective compared to first line treatment IFN $\beta-1 \mathrm{a}$ and placebo, in reducing the frequency of flare-ups (clinical exacerbations), disability progression, MRI outcome measures, including brain volume loss and was associated with clearly identified adverse events $[103,136,137]$. More than 180,000 patients have been treated with fingolimod in clinical trials and post-marketing settings globally, and the total patient exposure now exceeds 395,000 patient-years. Side effects include bradycardia (within $6 \mathrm{~h}$ after treatment initiation), blurred vision, diarrhea, back pain, headache, cough and vomiting. With reasonable data showing its long-term safety and disease improvement, fingolimod is a great alternative choice for patients with highly active RRMS and who prefer the oral treatment option.

\subsubsection{Mitoxantrone (Novantrone ${ }^{\circledR}$, Immunex/Amgen, Thousand Oaks, CA, USA)}

Mitoxantrone is primarily used to treat certain types of cancers, in particular, non-Hodgkin's lymphoma, acute myeloid leukemia, breast and prostate cancer. Mitoxantrone is a type-II topoisomerase inhibitor, which disrupts DNA synthesis and DNA repair of cancer cells, however, normal cells are also affected. It is a potent immune suppressant, suppressing $\mathrm{T}$ cells, $\mathrm{B}$ cells and 
macrophages and reduces pro-inflammatory cytokines (IFN- $\gamma$, TNF- $\alpha$, and IL-2) [138,139]. In patients with SPMS, intravenous injection of $12 \mathrm{mg} / \mathrm{m}^{2}$ mitoxantrone every 3 months up to 2 years resulted in reduced disability progression by $84 \%[140,141]$. However, several side effects are associated with mitoxantrone which range from nausea, vomiting, hair loss, to, cardiotoxicity, leukemia, infertility, infection, leukopenia and thrombocytopenia [11]. As a result, its use has significantly been reduced over time. Furthermore, due to the risk of cardiotoxicity and leukemia, there is a limit on the cumulative lifetime dose to be administered to patients [11,142].

\subsection{Treatment Using Humanized Monoclonal Antibodies}

\subsubsection{Natalizumab (Tysabr ${ }^{\circledR}$, Biogen, Cambridge, MA, USA)}

Natalizumab is a humanized monoclonal antibody against the cellular adhesion molecule $\alpha 4$ - integrin. Integrins are transmembrane receptors that enable cell-extracellular matrix adhesion activating cell signaling which regulate cell growth, division, survival, differentiation and migration. Integrins are expressed on T cells, B cells, monocytes, macrophages, NK cells, DC, neutrophils and eosinophils. Interfering or blocking $\alpha 4$-integrin affects immune cell migration across the blood brain barrier, thus, by blocking the interaction between $\alpha 4$-integrin and vascular endothelial adhesion molecule-1, inhibits transendothelial migration to the CNS [143]. Natalizumab is administered intravenously once a month [144] which reduces activated T cells within the CNS, resulting in anti-inflammatory responses and hence, neuroprotective effects [114]. In a phase III clinical trial natalizumab reduced brain lesions and the rate of disability progression up to 24 months $[12,145]$. In addition, natalizumab decreased by $92 \%$ of contrast-enhancing lesions, by $83 \%$ of new or expanding T2-weighted lesions, and by $76 \%$ in new T1-weighted hypointense lesions [146,147]. Natalizumab, was approved by the FDA in 2004, but was withdrawn due to 3 cases of rare brain infection, progressive multifocal leukoencephalopathy (PML; that usually leads to death or severe disability), but was re-introduced in 2006 under a special prescription program. However, by 2012 a further 212 cases (or 2.1/1000) of PML were reported to be attributed to natalizumab [148]. Despite these reports the FDA has not withdrawn natalizumab from the market as the clinical benefits outweigh the risks involved. Other side effects include, hepatotoxicity, allergic reactions and increased risks of infection. Due to the risks involved with natalizumab, there are reservations over its use as a preferred treatment option.

\subsubsection{Ofatumumab (Arzerra ${ }^{\circledR}$, Novartis Pharma AG, Basel, Switzerland)}

Ofatumumab (OMB157) is the first fully human type 1 IgG1 kappa (IgG1א) monoclonal antibody and is currently licensed for the treatment (of patients with chronic lymphocytic leukemia (intravenously (iv), Arzerra ${ }^{\circledR}$ ). It has also been shown to be beneficial to patients with rheumatoid arthritis, follicular non-Hodgkin's lymphoma, diffuse B cell lymphoma and MS. B cells play a role in the pathogenesis of MS. B cells have essential functions in regulating immune response, by activating $\mathrm{CD}^{+}{ }^{+} \mathrm{T}$-cells and regulating T-cell responses via the secretion of cytokines and antibodies. B cells are present at demyelinating areas and in cerebrospinal fluid of patients with MS [149]. CD20 is a marker and present on the cell surface of all B cells. In an attempt to reduce the number of B cells including autoreactive B cells, the use of anti-CD20 antibodies would conceivably improve MS relapses and progression. In fact, there are several humanized anti-CD20 antibodies, such as rituximab [150], ocrelizumab [151] and ofatumumab [152], which have shown high efficacy in patients with RRMS. In 2015, Novartis acquired the rights from GlaxoSmithKline for the development of ofatumumab in oncology and other autoimmune indications. Ofatumumab binds to 2 unique novel epitopes on the CD20 molecule, induces B-cell depletion via complement dependent cytotoxicity and antibody-dependent cell-mediated cytotoxicity causing B cell apoptosis [153]. Ofatumumab has demonstrated high efficacy in hematologic malignancies and in rheumatoid arthritis. Based on 2 Phase II dosing human clinical studies, ofatumumab demonstrated high efficacy in reducing new MRI lesion activity more than $90 \%$ and was well tolerated in patients with MS [152]. Currently, ofatumumab is 
being further investigated in 2 Phase III trials (ASCLEPIOS I AND ASCLEPIOS II) and are recruiting patients with relapsing forms of MS (ofatumumab versus teriflunomide). The adaptive study design of both trials was recently presented by Hauser SL and colleagues at the American Academy of Neurology April 2017 in Boston, USA and results are highly anticipated [154].

\subsubsection{Ocrelizumab (Ocrevus ${ }^{\circledR}$, Genentech Inc., San Fransisco, CA, USA)}

A few months ago (March 2017), the FDA approved ocrelizumab to be used in PPMS, the first drug approved by the FDA for this form of MS and phase IV clinical trials were a requirement of the FDA to be conducted in order to determine the safety of ocrelizumab in younger patients with MS, ie, risk of cancer and effects on pregnancy (study outcomes due by 2024); although clinical trials in patients with lupus and rheumatoid arthritis were halted due to high rates of infections and increased risk of progressive multifocal leukoencephalopathy [155]. In addition, in patients with MS, there was an increased risk of breast cancer (6/781 females with MS on ocrelizumab compared to $0 / 668$ females with MS in other trials) [155].

\subsubsection{Alemtuzumab (Lemtrada ${ }^{\circledR}$, Sanofi Genzyme, Cambridge, MA, USA)}

Alemtuzumab is a humanized monoclonal antibody against CD52, a cell surface molecule expressed on B and T cells; mature NK cells, plasma cells, neutrophils and importantly, hematological stem cells do not express CD52. In phase III clinical trials in patients with RRMS, alemtuzumab showed significantly lower annualized relapse rates and MRI measures (gadolinium-enhancing lesions, new or enlarging T2 lesions and brain atrophy) and were free of clinical disease longer, compared to IFN $\beta$-1a [156,157]. Alemtuzumab can cause serious side effects including, immune thrombocytopenia, kidney problems, serious infusion problems (trouble breathing, swelling, chest pain, irregular heart beat), certain cancers (blood cancers, thyroid cancer), cytopenia and serious infections. It was approved by the FDA in 2014 to be used in RRMS patients, but due to the frequent and significant adverse events of alemtuzumab, it is generally used in patients with RRMS who have used 2 or more MS drugs and have failed to work.

\subsubsection{Daclizumab (Zinbryta ${ }^{\circledR}$, Biogen, Cambridge, MA, USA)}

Daclizumab is a humanized monoclonal antibody against CD25, the IL-2 receptor expressed on the surface of T cells. The mechanism by which daclizumab works is that it blocks the IL-2 receptor on $\mathrm{T}$ cells, preventing the activation of T cells. It was originally approved by the FDA in 1997 to prevent acute kidney transplants (together with corticosteroids and cyclosporine) however its use was halted due to low market demand. In recent years its use has re-emerged to treat patients with RRMS, it is injected subcutaneously, once a month [158]. In human clinical trials, daclizumab showed $45 \%$ reduced annualized relapse rates and $54 \%$ lower in the number of new lesions [158]. The side effects associated with daclizumab are relatively minor compared to other MS drugs, and include infections, skin rashes and liver complications.

\section{New and Emerging Immunotherapeutic Strategies against MS}

Antigen/peptide specific immunotherapy or using immune cells (i.e., stems cells), aim to restore tolerance while avoiding the use of non-specific immunosuppressive drugs as describe in Section 3, is a promising approach to fight autoimmune diseases including MS. As such, a number of approaches have been utilized.

\subsection{Stem Cells}

Multipotent hematopoietic stem cells (HSC) are cells isolated either from the bone marrow, umbilical cord blood or peripheral blood and are transplanted into the recipient. More commonly used for hematological malignancies (leukemia, multiple myeloma) its application has also expanded into 
autoimmune diseases. The first report of a bone marrow transplant in 1997 in a chronic myelogenous leukemia patient with MS which showed marked improvements in MS brain lesions [159] quickly led to the use of HSC transplantation (HSCT) in MS patients. HSCT in patients with active RRMS, reduce progression in about $70 \%$ of patients, decrease relapses dramatically and suppresses inflammatory MRI activity [160]. MS patients who have not responded to conventional therapy, who's disease is aggressive with relapsing-remitting course and who are not presenting with high level of disability, are considered appropriate candidates for such treatment [161]. Although the clinical efficacy of HSCT long term has not been established. The mechanism by which HSCT works is that HSCT "reboots" the immune system and thus, prevents inflammation associated with the disease.

Mesenchymal stem cells (MSC) are isolated from an adult's bone marrow, are differentiated in vitro for 2-3 weeks and re-injected back into the patient. In recent years a vast amount of research has been conducted in MSCs to treat MS with most studies being in mice and EAE models, and more recently in human clinical trials. In fact, in a pilot study in advanced MS patients, MSC transplantation improved expanded disability scale score with stabilization in $1 / 7$ and disease progression in $1 / 7$ patients and vision and low contrast sensitivity test showed improvement in $5 / 6$ patients with $1 / 6$ showing worsening effects [162]. In a phase II randomized double-blind, placebo-controlled crossover clinical trial showed lower mean cumulative number of lesions in patients receiving MSCs compared to placebo [163]. No serious adverse events were reported. The mechanism of action of MSC includes immunomodulation, neuroprotection and neuroregeneration [162]. The use of MSCs that reduce MRI parameters is a new and emerging research focus to develop new improved treatments for MS.

\subsection{DNA Vaccine Studies}

BHT-3009, a DNA vaccine that encodes the full-length human MBP, was developed with the aim to tolerize patients with MS against MBP $[9,164,165]$. In fact, in 30 patients with RRMS or SPMS who received 4 injections of BHT-3009 on weeks 1, 3, 5, 9 with escalating doses of $0.5 \mathrm{mg}, 1.5 \mathrm{mg}$ or $3 \mathrm{mg}$ was reported to be safe and conferred positive changes on brain MRI and reduced the number of $\mathrm{CD}^{+} \mathrm{T}$ cells $[9,164,166]$. In addition, in a retrospective, randomized double blind, phase II study in 155 MS patients, BHT-3009 had no impact on the risk for persistent black holes (axonal loss and disability progression). However, there was a correlation to those who had generated high anti-IgM MBP antibodies to reduced risk of persistent black holes [167].

\subsection{Nanoparticles}

Nanoparticles have extensively been characterized and used as vaccine formulations in pre-clinical models of cancer and infectious diseases $[168,169]$. Polymeric biodegradable lactic-glycolic acid (PLGA) nanoparticles loaded with $\mathrm{MOG}_{35-55}$ peptide together with recombinant IL-10, were partially endocytozed by dendritic cells, secreted both $\mathrm{MOG}_{35-55}$ peptide and IL-10 in culture media for several weeks in vitro [170]. In mice, PLGA nanoparticles $\left(\mathrm{MOG}_{35-55}+\mathrm{IL}-10\right)$ showed significant amelioration of EAE and reduction of IL-17 and IFN-gamma secretion by splenic T cells in vitro [170]. Recently, poly( $\varepsilon$-caprolactone) nanoparticles loaded with recombinant human MBP reduced IFN-gamma cytokines, reduced the clinical score and showed only mild histological changes of the myelin sheath [171]. Hence, nanoparticles as a delivery method of self-antigens are a promising tool to treat MS.

\subsection{Altered Peptide Ligands}

Altered peptide ligands (APL) are peptides closely related to the native (agonist) peptide with defined 1-2 substituted amino acid residues which interact with the T cell receptor (TCR) yet retains its binding ability to the MHC [65]. In phase I/II clinical trial by Neurocrine Biosciences Inc, used an APL of $\mathrm{MBP}_{83-99}$, where L-amino acids were changed to D-amino acids at positions 83, 84, 89, 91 (NBI-5788) [172]. However, this mode of APL induced T cell cross reactivity between the APL and the wild-type/agonist $\mathrm{MBP}_{83-99}$ peptide and adverse events in some patients resulted [173]. A subsequent 
multi-center double-blinded phase II clinical trial with NBI-5788 was suspended-Th2 responses were induced (IL-5, IL-13), however, 13/142 patients developed immediate-type hypersensitivity, who also generated anti-NBI-5788 antibodies which cross-reacted with native agonist $\mathrm{MBP}_{83-99}$ peptide [172,174]. National Institute of Neurological Disorders and Stroke sponsored trial, CGP77116, was used in a MRI-controlled phase II clinical trial. CGP77116, has Ala D-amino acids of MBP $_{83-99}$ peptide at positions 83, 84, 89, 91 (CGP77116) of $\mathrm{MBP}_{83-99}$ peptide, in order to enhance stability [174]. However, this peptide was poorly tolerated at the dose tested, and the trial had to be discontinued. Three patients showed exacerbations to disease of which two were linked to CGP77116 injection with high IFN-gamma and low IL-4 (Th1-skewing) were secreted by activated CD4 ${ }^{+} \mathrm{T}$ cells. These CD4 ${ }^{+} \mathrm{T}$ cells also cross reacted with the native agonist $\mathrm{MBP}_{83-99}$ peptide [175]. Accordingly, the problems noted with both NBI-5788 and CGP77116 were likely due to inadequate pre-screening of APL effects on the many clonotypes against the targeted epitopes. Thus, although the APL was highly effective at blocking or switching some clones, it activated others. Thus, further pre-clinical testing is required and new modified peptides need to be designed, or a carrier needs to be used which further changes the resulting immune response.

\subsubsection{Cyclic Peptides}

Cyclization of peptides increases the stability, since linear peptides are sensitive to proteolytic enzymes. In addition, cyclic peptides are an important intermediate step and a useful template towards the rational design and development of non-peptide mimetics. While mimetic strategy is a challenging perspective it is worth pursuing in particular for MBP epitope-based MS therapy as it is still in its infancy. Efforts to design semi-mimetics of $\mathrm{MBP}_{72-85}$ epitope by combining non-natural amino acids as spacers and MBP epitope immunophores (Ser, Arg, Glu, Ala, Gln), led to substances that were effective to some extent in inducing the onset of EAE. Cyclic peptides are not only as a step towards non-peptide mimetics but also as putative therapeutics in MS [66].

Structure activity studies of the immunodominant agonist peptide $\mathrm{MBP}_{87-99}$, have shown that $\mathrm{K}^{91}, \mathrm{P}^{96}$ are important $\mathrm{T}$ cell receptor contact residues. Double mutation of $\mathrm{K}^{91}$, $\mathrm{P}^{96}$ to $\mathrm{R}^{91}$, $\mathrm{A}^{96}$ or single mutation of $\mathrm{P}^{96}$ to $\mathrm{A}^{96}$ (APL) of either in their linear or cyclic forms, results in suppression of EAE and decreased inflammation in the spinal cord of Lewis rats [71]. Single and double cyclic $\left[\mathrm{A}^{91}\right] \mathrm{MBP}_{83-99}$ peptide and cyclic $\left[\mathrm{A}^{91} \mathrm{~A}^{96}\right] \mathrm{MBP}_{83-99}$ peptides emulsified in CFA induced IL-4 cytokines in SJL/J mice [62] however conjugation to reduced mannan further enhanced IL-4 cytokines with no IFN-gamma responses [63]. In guinea pigs and Lewis rats, cyclic $\left[\mathrm{A}^{91} \mathrm{~A}^{96}\right] \mathrm{MBP}_{83-99}$ showed significantly reduced mechanical pain hypersensitivity compared to cyclic $\mathrm{MBP}_{83-99}$ peptide. This was associated with reduced $\mathrm{T}$ cell and macrophage infiltration to injured nerves of the spinal cord of animals [176-178]. In addition, these APL decreased $\mathrm{CD}^{+} \mathrm{T}$ cell line proliferation raised from a patient with MS, increased IL-10 cytokine secretion, bound to HLA-DR4 and were more stable to lysosomal enzymes (cathepsin B, D, H) compared to their linear counterparts [70]. Double mutation of $\mathrm{K}^{91}, \mathrm{P}^{96}$ to $A^{91}, A^{96}$ in either linear or cyclic forms were also shown to be active, with suppression of EAE in SJL/J mice, higher Th2 over Th1 cytokines produced, bound to HLA-DR4, the cyclic forms were more stable to lysosomal enzymes and induced high levels of IL-10 of peripheral blood mononuclear cells from patients with MS [61]. Recently, cyclic native agonist $\mathrm{MOG}_{35-55}$ peptide was shown to ameliorate clinical and neuropathological features of EAE in mice compared to its linear counterpart [179]. Thus, cyclic peptides, which offer greater stability and are able to modulate immune responses, are novel leads for the immunotherapy of many diseases, such as MS [66].

\subsubsection{Mannan as a Carrier to Modulate Immune Responses}

Mannan, a polymannose, isolated from the wall of yeast cells has been shown to bind to the mannose receptor on dendritic cells as well as being a ligand for toll-like receptor 4 [180,181]. Mannan conjugated to MUC1 cancer protein induces immune responses in mice and protects mice against tumor challenge. This work was translated into human phase I, II and pilot III clinical 
trials; mannan-MUC1 induces protection against cancer recurrence at 18 years follow-up [182-185]. Furthermore, ex vivo cultured dendritic cells pulsed with mannan-MUC1 (CVac $\left.{ }^{\mathrm{TM}}\right)$ and re-injection into patients induces strong cellular and clinical responses in ovarian cancer patients $[186,187]$. Due to the immunomodulatory properties of mannan, its effects as a carrier to MS peptides were determined.

Mutations of $\mathrm{MBP}_{83-99}$ agonist native peptide to result in mutant peptides (APL)-linear $\left[\mathrm{A}^{91}\right] \mathrm{MBP}_{83-99}, \quad\left[\mathrm{E}^{91}\right] \mathrm{MBP}_{83-99},\left[\mathrm{~F}^{91}\right] \mathrm{MBP}_{83-99}, \quad\left[\mathrm{Y}^{91}\right] \mathrm{MBP}_{83-99}$ and $\left[\mathrm{R}^{91}, \mathrm{~A}^{96}\right] \mathrm{MBP}_{83-99}$, induced IFN-gamma albeit reduced compared to the native agonist peptide, however, only the double APL $\left[R^{91}, A^{96}\right] M P_{83-99}$ induced IL-4 secretion by $T$ cells and antagonized IFN-gamma production in vitro by $\mathrm{T}$ cells against the native $\mathrm{MBP}_{83-99}$ peptide [67]. In addition, $\mathrm{T}$ cells against the native $\mathrm{MBP}_{83-99}$ peptide cross-reacted with all peptides except [ $\left.\mathrm{Y}^{91}\right] \mathrm{MBP}_{83-99}$ and $\left[\mathrm{R}^{91}, \mathrm{~A}^{96}\right] \mathrm{MBP}_{83-99}$ [68]. Conjugation of $\left.\left[\mathrm{R}^{91}, \mathrm{~A}^{96}\right] \mathrm{MBP}_{83-99},\left[\mathrm{~A}^{91}, \mathrm{~A}^{96}\right] \mathrm{MBP}_{83-99}, \mathrm{~F}^{91}\right] \mathrm{MBP}_{83-99},\left[\mathrm{Y}^{91}\right] \mathrm{MBP}_{83-99}$ peptides to mannan, completed abrogated IFN-gamma responses and elicited high IL-4 (i.e., Th1 to Th2 switch) $[63,69,188]$. Likewise, linear double-mutant APL $\left[\mathrm{L}^{144} \mathrm{R}^{147}\right] \mathrm{PLP} \mathrm{P}_{139-151}$ induces high levels of IL-4, and cyclization of this analog elicited low levels of IFN-gamma. When conjugated to mannan, $\left[\mathrm{L}^{144} \mathrm{R}^{147}\right] \mathrm{PLP}{ }_{139-151}$ peptide completely abrogated IFN-gamma, while both linear and cyclic native agonist $\mathrm{PLP}_{139-151}$ peptides stimulated IFN-gamma secreting $\mathrm{T}$ cells [64]. Furthermore, mannan conjugated to the immunodominant agonist $\mathrm{MOG}_{35-55}$ peptide primes non-pathogenic Th1 and Th17 cells and ameliorates EAE in mice [73]; a phase I human clinical trial is planned using mannan conjugated to $\mathrm{MOG}_{35-55}$ peptide later this year. It is clear that, mannan is able to divert immune responses from Th1 to Th2 and is a promising carrier for further studies for the development of immunotherapeutics against MS.

\section{Symptomatic Medication}

\section{Dalfampridine (Ampyra/Fampyra ${ }^{\circledR}$, Acorda Therapeutics)}

Dalfampridine is not intended to delay symptoms or change the course of disease, but rather, to improve motor symptoms such as walking. Dalfampridine, is a potassium channel blocker, resulting in improved potassium currents and nerve conductance. Dalfampridine is used in patients who have had MS for more than 3 years and it was approved by the FDA in 2010. Common side effects include nausea, nervousness and dizziness, which are relatively minor compared to other MS drugs.

\section{Conclusions and Future Prospects}

MS is an autoimmune disorder of the CNS with an array of immune cells being either activated or suppressed leading to demyelination and disease progression. In addition, genetic predisposition, viral mimicry, vitamin and mineral deficiency, geographical location are also etiological factors that contribute to disease. More recently, citrulination of myelin peptides have been shown to contribute to disease activation $[59,60]$. A number of treatment options are available to patients with MS, in particular those with active disease, however due to side effects, limited long term effectiveness and inability to reverse disease, new improved treatment options are required. As described here a number of new and upcoming promising therapeutic candidates are becoming available, although their effectiveness in human clinical trials remains to be determined. Recently, it was reported that non-peptide mimetics mapping the $\mathrm{MBP}_{83-96} \mathrm{~T}$ cell epitope can function as $\mathrm{T}$ cell receptor antagonists, hence such an approach may pave the way to developing alternative and improved immunotherapeutics against MS [189]. With the plethora of information regarding the immunopathophysiology of MS and availability of treatment options and new upcoming treatments, the future holds promise for managing and treating the disease.

Acknowledgments: V.A. would like to thank Vianex S.A. Greece for support (Specific task agreement MS immunotherapeutics). V.A. and J.M. would like to thank Vianex S.A. Greece for their enthusiasm, support and helpful discussions regarding drug development and immunotherapeutics against MS.

Author Contributions: N.D. and V.A. wrote the article and all authors reviewed and edited the article. 
Conflicts of Interest: V.A. is supported by Vianex S.A. Greece in developing immunotherapeutics against MS; N.D. is supported under VU-Vianex contract 2 (specific task agreement MS immunotherapeutics) in developing immunotherapeutics against MS; J.M. is head of the scientific advisory board of ELDrug a spin off company of Vianex S.A.; M.-E.A. works for Vianex S.A. Greece; T.T. has an association with Vianex S.A. Greece in relation to supporting his research; M.K. is an employee of Novartis (Hellas) Greece; M.d.C. declares no conflicts of interest. The review represents a detailed literature search in the areas of drugs and treatments against MS with no bias towards immunotherapeutics developed by Vianex S.A.

\section{References}

1. Compston, A.; Coles, A. Multiple sclerosis. Lancet 2002, 359, 1221-1231. [CrossRef]

2. Grytten, N.; Torkildsen, O.; Myhr, K.M. Time trends in the incidence and prevalence of multiple sclerosis in norway during eight decades. Acta Neurol. Scand. 2015, 132, 29-36. [CrossRef] [PubMed]

3. Antel, J.; Antel, S.; Caramanos, Z.; Arnold, D.L.; Kuhlmann, T. Primary progressive multiple sclerosis: Part of the ms disease spectrum or separate disease entity? Acta Neuropathol. 2012, 123, 627-638. [CrossRef] [PubMed]

4. Sadovnick, A.D.; Ebers, G.C.; Dyment, D.A.; Risch, N.J. Evidence for genetic basis of multiple sclerosis. Lancet 1996, 347, 1728-1730. [CrossRef]

5. Dai, H.; Ciric, B.; Zhang, G.X.; Rostami, A. Interleukin-10 plays a crucial role in suppression of experimental autoimmune encephalomyelitis by bowman-birk inhibitor. J. Neuroimmunol. 2012, 245, 1-7. [CrossRef] [PubMed]

6. Hemmer, B.; Nessler, S.; Zhou, D.; Kieseier, B.; Hartung, H.P. Immunopathogenesis and immunotherapy of multiple sclerosis. Nat. Clin. Pract. Neurol. 2006, 2, 201-211. [CrossRef] [PubMed]

7. Sospedra, M.; Martin, R. Immunology of multiple sclerosis. Annu. Rev. Immunol. 2005, 23, 683-747. [CrossRef] [PubMed]

8. Rieckmann, P. Improving ms patient care. J. Neurol. Suppl. 2004, 251, v69-v73. [CrossRef] [PubMed]

9. Katsara, M.; Matsoukas, J.; Deraos, G.; Apostolopoulos, V. Towards immunotherapeutic drugs and vaccines against multiple sclerosis. Acta Biochim. Biophys. Sin. 2008, 40, 636-642. [CrossRef] [PubMed]

10. Lublin, F.D.; Reingold, S.C. Defining the clinical course of multiple sclerosis: Results of an international survey. Neurology 1996, 46, 907-911. [CrossRef] [PubMed]

11. Eckstein, C.; Bhatti, M.T. Currently approved and emerging oral therapies in multiple sclerosis: An update for the ophthalmologist. Surv. Ophthalmol. 2016, 61, 318-332. [CrossRef] [PubMed]

12. Polman, C.H.; Reingold, S.C.; Banwell, B.; Clanet, M.; Cohen, J.A.; Filippi, M.; Fujihara, K.; Havrdova, E.; Hutchinson, M.; Kappos, L.; et al. Diagnostic criteria for multiple sclerosis: 2010 revisions to the mcdonald criteria. Ann. Neurol. 2011, 69, 292-302. [CrossRef] [PubMed]

13. Lunde Larsen, L.S.; Larsson, H.B.W.; Frederiksen, J.L. The value of conventional high-field mri in ms in the light of the mcdonald criteria: A literature review. Acta Neurol. Scand. 2010, 122, 149-158. [CrossRef] [PubMed]

14. Gafson, A.; Giovannoni, G.; Hawkes, C.H. The diagnostic criteria for multiple sclerosis: From charcot to mcdonald. Mult. Scler. Relat. Disord. 2012, 1, 9-14. [CrossRef] [PubMed]

15. Mahad, D.H.; Trapp, B.D.; Lassmann, H. Pathological mechanisms in progressive multiple sclerosis. Lancet Neurol. 2015, 14, 183-193. [CrossRef]

16. Minagar, A.; Alexander, J.S. Blood-brain barrier disruption in multiple sclerosis. Mult. Scler. 2003, 9, 540-549. [CrossRef] [PubMed]

17. Steinman, L. Multiple sclerosis: A coordinated immunological attack against myelin in the central nervous system. Cell 1996, 85, 299-302. [CrossRef]

18. Bennett, J.; Basivireddy, J.; Kollar, A.; Biron, K.E.; Reickmann, P.; Jefferies, W.A.; McQuaid, S. Blood-brain barrier disruption and enhanced vascular permeability in the multiple sclerosis model eae. J. Neuroimmunol. 2010, 229, 180-191. [CrossRef] [PubMed]

19. Farjam, M.; Zhang, G.X.; Ciric, B.; Rostami, A. Emerging immunopharmacological targets in multiple sclerosis. J. Neurol. Sci. 2015, 358, 22-30. [CrossRef] [PubMed]

20. Dandekar, A.A.; Wu, G.F.; Pewe, L.; Perlman, S. Axonal damage is t cell mediated and occurs concomitantly with demyelination in mice infected with a neurotropic coronavirus. J. Virol. 2001, 75, 6115-6120. [CrossRef] [PubMed] 
21. Jiang, J.; Kelly, K.A. Phenotype and function of regulatory t cells in the genital tract. Curr. Trends Immunol. 2011, 12, 89-94. [PubMed]

22. Bianchini, E.; De Biasi, S.; Simone, A.M.; Ferraro, D.; Sola, P.; Cossarizza, A.; Pinti, M. Invariant natural killer T cells and mucosal-associated invariant T cells in multiple sclerosis. Immunol. Lett. 2017, 183, 1-7. [CrossRef] [PubMed]

23. Tabarkiewicz, J.; Pogoda, K.; Karczmarczyk, A.; Pozarowski, P.; Giannopoulos, K. The role of il-17 and th17 lymphocytes in autoimmune diseases. Arch. Immunol. Ther. Exp. 2015, 63, 435-449. [CrossRef] [PubMed]

24. Van Hamburg, J.P.; Asmawidjaja, P.S.; Davelaar, N.; Mus, A.M.C.; Colin, E.M.; Hazes, J.M.W.; Dolhain, R.J.E.M.; Lubberts, E. Th17 cells, but not th1 cells, from patients with early rheumatoid arthritis are potent inducers of matrix metalloproteinases and proinflammatory cytokines upon synovial fibroblast interaction, including autocrine interleukin-17a production. Arthritis Rheum. 2011, 63, 73-83. [CrossRef] [PubMed]

25. Dolati, S.; Babaloo, Z.; Jadidi-Niaragh, F.; Ayromlou, H.; Sadreddini, S.; Yousefi, M. Multiple sclerosis: Therapeutic applications of advancing drug delivery systems. Biomed. Pharmacother. 2017, 86, 343-353. [CrossRef] [PubMed]

26. Münzel, E.J.; Williams, A. Promoting remyelination in multiple sclerosis-recent advances. Drugs 2013, 73, 2017-2029. [CrossRef] [PubMed]

27. Inglese, M.; Petracca, M. Therapeutic strategies in multiple sclerosis: A focus on neuroprotection and repair and relevance to schizophrenia. Schizophr. Res. 2015, 161, 94-101. [CrossRef] [PubMed]

28. Koriem, K.M.M. Multiple sclerosis: New insights and trends. Asian Pac. J. Trop. Biomed. 2016, 6, 429-440. [CrossRef]

29. Kallaur, A.P.; Lopes, J.; Oliveira, S.R.; Simão, A.N.; Reiche, E.M.; de Almeida, E.R.D.; Morimoto, H.K.; de Pereira, W.L.; Alfieri, D.F.; Borelli, S.D.; et al. Immune-inflammatory and oxidative and nitrosative stress biomarkers of depression symptoms in subjects with multiple sclerosis: Increased peripheral inflammation but less acute neuroinflammation. Mol. Neurobiol. 2016, 53, 5191-5202. [CrossRef] [PubMed]

30. Mirshafiey, A.; Jadidi-Niaragh, F. Prostaglandins in pathogenesis and treatment of multiple sclerosis. Immunopharmacol. Immunotoxicol. 2010, 32, 543-554. [CrossRef] [PubMed]

31. Fischer, M.T.; Sharma, R.; Lim, J.L.; Haider, L.; Frischer, J.M.; Drexhage, J.; Mahad, D.; Bradl, M.; Van Horssen, J.; Lassmann, H. Nadph oxidase expression in active multiple sclerosis lesions in relation to oxidative tissue damage and mitochondrial injury. Brain 2012, 135, 886-899. [CrossRef] [PubMed]

32. Van Kaer, L.; Wu, L.; Parekh, V.V. Natural killer $t$ cells in multiple sclerosis and its animal model, experimental autoimmune encephalomyelitis. Immunology 2015, 146, 1-10. [CrossRef] [PubMed]

33. Gigli, G.; Caielli, S.; Cutuli, D.; Falcone, M. Innate immunity modulates autoimmunity: Type 1 interferon-beta treatment in multiple sclerosis promotes growth and function of regulatory invariant natural killer $\mathrm{t}$ cells through dendritic cell maturation. Immunology 2007, 122, 409-417. [CrossRef] [PubMed]

34. Araki, M.; Kondo, T.; Gumperz, J.E.; Brenner, M.B.; Miyake, S.; Yamamura, T. Th2 bias of cd4+ nkt cells derived from multiple sclerosis in remission. Int. Immunol. 2003, 15, 279-288. [CrossRef] [PubMed]

35. Mars, L.T.; Laloux, V.; Goude, K.; Desbois, S.; Saoudi, A.; Van Kaer, L.; Lassmann, H.; Herbelin, A.; Lehuen, A.; Liblau, R.S. Cutting edge: V alpha 14-j alpha $281 \mathrm{nkt}$ cells naturally regulate experimental autoimmune encephalomyelitis in nonobese diabetic mice. J. Immunol. 2002, 168, 6007-6011. [CrossRef] [PubMed]

36. Van Kaer, L. Alpha-galactosylceramide therapy for autoimmune diseases: Prospects and obstacles. Nat. Rev. Immunol. 2005, 5, 31-42. [CrossRef] [PubMed]

37. Van Kaer, L.; Parekh, V.V.; Wu, L. Invariant nk t cells: Potential for immunotherapeutic targeting with glycolipid antigens. Immunotherapy 2011, 3, 59-75. [CrossRef] [PubMed]

38. Jahng, A.; Maricic, I.; Aguilera, C.; Cardell, S.; Halder, R.C.; Kumar, V. Prevention of autoimmunity by targeting a distinct, noninvariant cd1d-reactive $t$ cell population reactive to sulfatide. J. Exp. Med. 2004, 199, 947-957. [CrossRef] [PubMed]

39. Napier, R.J.; Adams, E.J.; Gold, M.C.; Lewinsohn, D.M. The role of mucosal associated invariant t cells in antimicrobial immunity. Front. Immunol. 2015, 6, 344. [CrossRef] [PubMed]

40. Kjer-Nielsen, L.; Patel, O.; Corbett, A.J.; Le Nours, J.; Meehan, B.; Liu, L.; Bhati, M.; Chen, Z.; Kostenko, L.; Reantragoon, R.; et al. Mr1 presents microbial vitamin b metabolites to mait cells. Nature 2012, 491, 717-723. [CrossRef] [PubMed] 
41. Abrahamsson, S.V.; Angelini, D.F.; Dubinsky, A.N.; Morel, E.; Oh, U.; Jones, J.L.; Carassiti, D.; Reynolds, R.; Salvetti, M.; Calabresi, P.A.; et al. Non-myeloablative autologous haematopoietic stem cell transplantation expands regulatory cells and depletes il-17 producing mucosal-associated invariant $\mathrm{t}$ cells in multiple sclerosis. Brain 2013, 136, 2888-2903. [CrossRef] [PubMed]

42. Miyazaki, Y.; Miyake, S.; Chiba, A.; Lantz, O.; Yamamura, T. Mucosal-associated invariant t cells regulate th1 response in multiple sclerosis. Int. Immunol. 2011, 23, 529-535. [CrossRef] [PubMed]

43. Kohm, A.P.; Carpentier, P.A.; Anger, H.A.; Miller, S.D. Cutting edge: CD4+CD25+ regulatory t cells suppress antigen-specific autoreactive immune responses and central nervous system inflammation during active experimental autoimmune encephalomyelitis. J. Immunol. 2002, 169, 4712-4716. [CrossRef] [PubMed]

44. Zhang, X.; Koldzic, D.N.; Izikson, L.; Reddy, J.; Nazareno, R.F.; Sakaguchi, S.; Kuchroo, V.K.; Weiner, H.L. Il-10 is involved in the suppression of experimental autoimmune encephalomyelitis by CD25+CD4+ regulatory t cells. Int. Immunol. 2004, 16, 249-256. [CrossRef] [PubMed]

45. McGeachy, M.J.; Stephens, L.A.; Anderton, S.M. Natural recovery and protection from autoimmune encephalomyelitis: Contribution of CD4+CD25+ regulatory cells within the central nervous system. J. Immunol. 2005, 175, 3025-3032. [CrossRef] [PubMed]

46. Matejuk, A.; Bakke, A.C.; Hopke, C.; Dwyer, J.; Vandenbark, A.A.; Offner, H. Estrogen treatment induces a novel population of regulatory cells, which suppresses experimental autoimmune encephalomyelitis. J. Neurosci. Res. 2004, 77, 119-126. [CrossRef] [PubMed]

47. Weber, M.S.; Prod'homme, T.; Youssef, S.; Dunn, S.E.; Rundle, C.D.; Lee, L.; Patarroyo, J.C.; Stuve, O.; Sobel, R.A.; Steinman, L.; et al. Type ii monocytes modulate $t$ cell-mediated central nervous system autoimmune disease. Nat. Med. 2007, 13, 935-943. [CrossRef] [PubMed]

48. Beyersdorf, N.; Gaupp, S.; Balbach, K.; Schmidt, J.; Toyka, K.V.; Lin, C.H.; Hanke, T.; Hunig, T.; Kerkau, T.; Gold, R. Selective targeting of regulatory $\mathrm{t}$ cells with $\mathrm{cd} 28$ superagonists allows effective therapy of experimental autoimmune encephalomyelitis. J. Exp. Med. 2005, 202, 445-455. [CrossRef] [PubMed]

49. Zozulya, A.L.; Wiendl, H. The role of regulatory t cells in multiple sclerosis. Nat. Clin. Pract. Neurol. 2008, 4, 384-398. [CrossRef] [PubMed]

50. Diebold, M.; Derfuss, T. Immunological treatment of multiple sclerosis. Semin. Hematol. 2016, 53 (Suppl. 1), S54-S57. [CrossRef] [PubMed]

51. Mosser, D.M.; Edwards, J.P. Exploring the full spectrum of macrophage activation. Nat. Rev. Immunol. 2008, 8, 958-969. [CrossRef] [PubMed]

52. Bruck, W.; Sommermeier, N.; Bergmann, M.; Zettl, U.; Goebel, H.H.; Kretzschmar, H.A.; Lassmann, H. Macrophages in multiple sclerosis. Immunobiology 1996, 195, 588-600. [CrossRef]

53. Vogel, D.Y.; Vereyken, E.J.; Glim, J.E.; Heijnen, P.D.; Moeton, M.; van der Valk, P.; Amor, S.; Teunissen, C.E.; van Horssen, J.; Dijkstra, C.D. Macrophages in inflammatory multiple sclerosis lesions have an intermediate activation status. J. Neuroinflamm. 2013, 10, 35. [CrossRef] [PubMed]

54. Peferoen, L.A.; Vogel, D.Y.; Ummenthum, K.; Breur, M.; Heijnen, P.D.; Gerritsen, W.H.; Peferoen-Baert, R.M.; van der Valk, P.; Dijkstra, C.D.; Amor, S. Activation status of human microglia is dependent on lesion formation stage and remyelination in multiple sclerosis. J. Neuropathol. Exp. Neurol. 2015, 74, 48-63. [CrossRef] [PubMed]

55. Miron, V.E.; Boyd, A.; Zhao, J.W.; Yuen, T.J.; Ruckh, J.M.; Shadrach, J.L.; van Wijngaarden, P.; Wagers, A.J.; Williams, A.; Franklin, R.J.; et al. M2 microglia and macrophages drive oligodendrocyte differentiation during cns remyelination. Nat. Neurosci. 2013, 16, 1211-1218. [CrossRef] [PubMed]

56. Liu, C.; Li, Y.; Yu, J.; Feng, L.; Hou, S.; Liu, Y.; Guo, M.; Xie, Y.; Meng, J.; Zhang, H.; et al. Targeting the shift from $\mathrm{m} 1$ to $\mathrm{m} 2$ macrophages in experimental autoimmune encephalomyelitis mice treated with fasudil. PLoS ONE 2013, 8, e54841. [CrossRef] [PubMed]

57. Apostolopoulos, V.; de Courten, M.P.; Stojanovska, L.; Blatch, G.L.; Tangalakis, K.; de Courten, B. The complex immunological and inflammatory network of adipose tissue in obesity. Mol. Nutr. Food Res. 2016, 60, 43-57. [CrossRef] [PubMed]

58. Wu, Q.; Wang, Q.; Mao, G.; Dowling, C.A.; Lundy, S.K.; Mao-Draayer, Y. Dimethyl fumarate selectively reduces memory $t$ cells and shifts the balance between th1/th17 and th2 in multiple sclerosis patients. J. Immunol. 2017, 198, 3069-3080. [CrossRef] [PubMed] 
59. Apostolopoulos, V.; Deraos, G.; Matsoukas, M.T.; Day, S.; Stojanovska, L.; Tselios, T.; Androutsou, M.E.; Matsoukas, J. Cyclic citrullinated mbp87-99 peptide stimulates t cell responses: Implications in triggering disease. Bioorg. Med. Chem. 2017, 25, 528-538. [CrossRef] [PubMed]

60. Deraos, G.; Chatzantoni, K.; Matsoukas, M.T.; Tselios, T.; Deraos, S.; Katsara, M.; Papathanasopoulos, P.; Vynios, D.; Apostolopoulos, V.; Mouzaki, A.; et al. Citrullination of linear and cyclic altered peptide ligands from myelin basic protein $(\mathrm{mbp}(87-99))$ epitope elicits a th1 polarized response by $\mathrm{t}$ cells isolated from multiple sclerosis patients: Implications in triggering disease. J. Med. Chem. 2008, 51, 7834-7842. [CrossRef] [PubMed]

61. Deraos, G.; Rodi, M.; Kalbacher, H.; Chatzantoni, K.; Karagiannis, F.; Synodinos, L.; Plotas, P.; Papalois, A.; Dimisianos, N.; Papathanasopoulos, P.; et al. Properties of myelin altered peptide ligand cyclo(87-99) (ala91,ala96)mbp87-99 render it a promising drug lead for immunotherapy of multiple sclerosis. Eur. J. Med. Chem. 2015, 101, 13-23. [CrossRef] [PubMed]

62. Katsara, M.; Deraos, G.; Tselios, T.; Matsoukas, J.; Apostolopoulos, V. Design of novel cyclic altered peptide ligands of myelin basic protein mbp83-99 that modulate immune responses in sjl/j mice. J. Med. Chem. 2008, 51, 3971-3978. [CrossRef] [PubMed]

63. Katsara, M.; Deraos, G.; Tselios, T.; Matsoukas, M.T.; Friligou, I.; Matsoukas, J.; Apostolopoulos, V. Design and synthesis of a cyclic double mutant peptide (cyclo(87-99)[a91,a96]mbp87-99) induces altered responses in mice after conjugation to mannan: Implications in the immunotherapy of multiple sclerosis. J. Med. Chem. 2009, 52, 214-218. [CrossRef] [PubMed]

64. Katsara, M.; Deraos, S.; Tselios, T.V.; Pietersz, G.; Matsoukas, J.; Apostolopoulos, V. Immune responses of linear and cyclic plp139-151 mutant peptides in sjl/j mice: Peptides in their free state versus mannan conjugation. Immunotherapy 2014, 6, 709-724. [CrossRef] [PubMed]

65. Katsara, M.; Minigo, G.; Plebanski, M.; Apostolopoulos, V. The good, the bad and the ugly: How altered peptide ligands modulate immunity. Expert Opin. Biol. Ther. 2008, 8, 1873-1884. [CrossRef] [PubMed]

66. Katsara, M.; Tselios, T.; Deraos, S.; Deraos, G.; Matsoukas, M.T.; Lazoura, E.; Matsoukas, J.; Apostolopoulos, V. Round and round we go: Cyclic peptides in disease. Curr. Med. Chem. 2006, 13, 2221-2232. [PubMed]

67. Katsara, M.; Yuriev, E.; Ramsland, P.A.; Deraos, G.; Tselios, T.; Matsoukas, J.; Apostolopoulos, V. A double mutation of mbp83-99 peptide induces il-4 responses and antagonizes ifn- $\gamma$ responses. J. Neuroimmunol. 2008, 200, 77-89. [CrossRef] [PubMed]

68. Katsara, M.; Yuriev, E.; Ramsland, P.A.; Deraos, G.; Tselios, T.; Matsoukas, J.; Apostolopoulos, V. Mannosylation of mutated mbp83-99 peptides diverts immune responses from th1 to th2. Mol. Immunol. 2008, 45, 3661-3670. [CrossRef] [PubMed]

69. Katsara, M.; Yuriev, E.; Ramsland, P.A.; Tselios, T.; Deraos, G.; Lourbopoulos, A.; Grigoriadis, N.; Matsoukas, J.; Apostolopoulos, V. Altered peptide ligands of myelin basic protein (mbp87-99) conjugated to reduced mannan modulate immune responses in mice. Immunology 2009, 128, 521-533. [CrossRef] [PubMed]

70. Matsoukas, J.; Apostolopoulos, V.; Kalbacher, H.; Papini, A.M.; Tselios, T.; Chatzantoni, K.; Biagioli, T.; Lolli, F.; Deraos, S.; Papathanassopoulos, P.; et al. Design and synthesis of a novel potent myelin basic protein epitope 87-99 cyclic analogue: Enhanced stability and biological properties of mimics render them a potentially new class of immunomodulators. J. Med. Chem. 2005, 48, 1470-1480. [CrossRef] [PubMed]

71. Tselios, T.; Apostolopoulos, V.; Daliani, I.; Deraos, S.; Grdadolnik, S.; Mavromoustakos, T.; Melachrinou, M.; Thymianou, S.; Probert, L.; Mouzaki, A.; et al. Antagonistic effects of human cyclic mbp(87-99) altered peptide ligands in experimental allergic encephalomyelitis and human t-cell proliferation. J. Med. Chem. 2002, 45, 275-283. [CrossRef] [PubMed]

72. Tselios, T.V.; Lamari, F.N.; Karathanasopoulou, I.; Katsara, M.; Apostolopoulos, V.; Pietersz, G.A.; Matsoukas, J.M.; Karamanos, N.K. Synthesis and study of the electrophoretic behavior of mannan conjugates with cyclic peptide analogue of myelin basic protein using lysine-glycine linker. Anal. Biochem. 2005, 347, 121-128. [CrossRef] [PubMed]

73. Tseveleki, V.; Tselios, T.; Kanistras, I.; Koutsoni, O.; Karamita, M.; Vamvakas, S.S.; Apostolopoulos, V.; Dotsika, E.; Matsoukas, J.; Lassmann, H.; et al. Mannan-conjugated myelin peptides prime non-pathogenic th1 and th17 cells and ameliorate experimental autoimmune encephalomyelitis. Exp. Neurol. 2015, 267, 254-267. [CrossRef] [PubMed]

74. Deng, Y.; Wang, Z.; Chang, C.; Lu, L.; Lau, C.S.; Lu, Q. Th9 cells and il-9 in autoimmune disorders: Pathogenesis and therapeutic potentials. Hum. Immunol. 2017, 78, 120-128. [CrossRef] [PubMed] 
75. Volpe, E.; Batistini, L.; Borsellino, G. Advances in $\mathrm{t}$ helper 17 cell biology: Pathogenic role and potential therapy in multiple sclerosis. Mediat. Inflamm. 2015, 475158. [CrossRef] [PubMed]

76. Rolla, S.; Bardina, V.; De Mercanti, S.; Quaglino, P.; De Palma, R.; Gned, D.; Brusa, D.; Durelli, L.; Novelli, F.; Clerico, M. Th22 cells are expanded in multiple sclerosis and are resistant to ifn-beta. J. Leukoc. Biol. 2014, 96, 1155-1164. [CrossRef] [PubMed]

77. Muls, N.; Nasr, Z.; Dang, H.A.; Sindic, C.; van Pesch, V. Il-22, gm-csf and il-17 in peripheral CD4+ t cell subpopulations during multiple sclerosis relapses and remission. Impact of corticosteroid therapy. PLoS ONE 2017, 12, e0173780. [CrossRef] [PubMed]

78. Iwasaki, Y.; Fujio, K.; Okamura, T.; Yamamoto, K. Interleukin-27 in t cell immunity. Int. J. Mol. Sci. 2015, 16, 2851-2863. [CrossRef] [PubMed]

79. Naderi, S.; Hejazi, Z.; Shajarian, M.; Alsahebfosoul, F.; Etemadifar, M.; Sedaghat, N. Il-27 plasma level in relapsing remitting multiple sclerosis subjects: The double-faced cytokine. J. Immunoass. Immunochem. 2016, 37, 659-670. [CrossRef] [PubMed]

80. Senecal, V.; Deblois, G.; Beauseigle, D.; Schneider, R.; Brandenburg, J.; Newcombe, J.; Moore, C.S.; Prat, A.; Antel, J.; Arbour, N. Production of il-27 in multiple sclerosis lesions by astrocytes and myeloid cells: Modulation of local immune responses. Glia 2016, 64, 553-569. [CrossRef] [PubMed]

81. Kawanokuchi, J.; Takeuchi, H.; Sonobe, Y.; Mizuno, T.; Suzumura, A. Interleukin-27 promotes inflammatory and neuroprotective responses in microglia. Clin. Exp. Neuroimmunol. 2013, 4, 36-45. [CrossRef]

82. Sawcer, S.; Hellenthal, G. The major histocompatibility complex and multiple sclerosis: A smoking gun? Brain 2011, 134, 638-640. [CrossRef] [PubMed]

83. Dressel, A.; Chin, J.L.; Sette, A.; Gausling, R.; Hollsberg, P.; Hafler, D.A. Autoantigen recognition by human cd8 t cell clones: Enhanced agonist response induced by altered peptide ligands. J. Immunol. 1997, 159, 4943-4951. [PubMed]

84. Tzartos, J.S.; Friese, M.A.; Craner, M.J.; Palace, J.; Newcombe, J.; Esiri, M.M.; Fugger, L. Interleukin-17 production in central nervous system-infiltrating t cells and glial cells is associated with active disease in multiple sclerosis. Am. J. Pathol. 2008, 172, 146-155. [CrossRef] [PubMed]

85. Salehi, Z.; Doosti, R.; Beheshti, M.; Janzamin, E.; Sahraian, M.A.; Izad, M. Differential frequency of CD8+ T cell subsets in multiple sclerosis patients with various clinical patterns. PLoS ONE 2016, 11, e0159565. [CrossRef] [PubMed]

86. Disanto, G.; Morahan, J.M.; Barnett, M.H.; Giovannoni, G.; Ramagopalan, S.V. The evidence for a role of b cells in multiple sclerosis. Neurology 2012, 78, 823-832. [CrossRef] [PubMed]

87. Wekerle, H. B cells in multiple sclerosis. Autoimmunity 2017, 50, 57-60. [CrossRef] [PubMed]

88. Winger, R.C.; Zamvil, S.S. Antibodies in multiple sclerosis oligoclonal bands target debris. Proc. Natl. Acad. Sci. USA 2016, 113, 7696-7698. [CrossRef] [PubMed]

89. Huang, Y.M.; Xiao, B.G.; Ozenci, V.; Kouwenhoven, M.; Teleshova, N.; Fredrikson, S.; Link, H. Multiple sclerosis is associated with high levels of circulating dendritic cells secreting pro-inflammatory cytokines. J. Neuroimmunol. 1999, 99, 82-90. [CrossRef]

90. Kong, Y.Y.; Fuchsberger, M.; Xiang, S.D.; Apostolopoulos, V.; Plebanski, M. Myeloid derived suppressor cells and their role in diseases. Curr. Med. Chem. 2013, 20, 1437-1444. [CrossRef] [PubMed]

91. Wegner, A.; Verhagen, J.; Wraith, D.C. Myeloid-derived suppressor cells mediate tolerance induction in autoimmune disease. Immunology 2017, 151, 26-42. [CrossRef] [PubMed]

92. Yu, J.; Du, W.; Yan, F.; Wang, Y.; Li, H.; Cao, S.; Yu, W.; Shen, C.; Liu, J.; Ren, X. Myeloid-derived suppressor cells suppress antitumor immune responses through ido expression and correlate with lymph node metastasis in patients with breast cancer. J. Immunol. 2013, 190, 3783-3797. [CrossRef] [PubMed]

93. Filippini, G.; Brusaferri, F.; Sibley, W.A.; Citterio, A.; Ciucci, G.; Midgard, R.; Candelise, L. Corticosteroids or acth for acute exacerbations in multiple sclerosis. Cochrane Database Syst. Rev. 2000. [CrossRef]

94. Havrdova, E.; Zivadinov, R.; Krasensky, J.; Dwyer, M.G.; Novakova, I.; Dolezal, O.; Ticha, V.; Dusek, L.; Houzvickova, E.; Cox, J.L.; et al. Randomized study of interferon beta-1a, low-dose azathioprine, and low-dose corticosteroids in multiple sclerosis. Mult. Scler. 2009, 15, 965-976. [CrossRef] [PubMed]

95. Morrow, S.A.; Metz, L.M.; Kremenchutzky, M. High dose oral steroids commonly used to treat relapses in canadian ms clinics. Can. J. Neurol. Sci. 2009, 36, 213-215. [CrossRef] [PubMed]

96. Myhr, K.M.; Mellgren, S.I. Corticosteroids in the treatment of multiple sclerosis. Acta Neurol. Scand. 2009, 120, 73-80. [CrossRef] [PubMed] 
97. Van Der Voort, L.F.; Visser, A.; Knol, D.L.; Oudejans, C.B.M.; Polman, C.H.; Killestein, J. Lack of interferon-beta bioactivity is associated with the occurrence of relapses in multiple sclerosis. Eur. J. Neurol. 2009, 16, 1049-1052. [CrossRef] [PubMed]

98. Kappos, L.; Freedman, M.S.; Polman, C.H.; Edan, G.; Hartung, H.-P.; Miller, D.H.; Montalbán, X.; Barkhof, F.; Radü, E.-W.; Bauer, L.; et al. Effect of early versus delayed interferon beta-1b treatment on disability after a first clinical event suggestive of multiple sclerosis: A 3-year follow-up analysis of the benefit study. Lancet 2007, 370, 389-397. [CrossRef]

99. Kappos, L.; Polman, C.H.; Freedman, M.S.; Edan, G.; Hartung, H.P.; Miller, D.H.; Montalban, X.; Barkhof, F.; Bauer, L.; Jakobs, P.; et al. Treatment with interferon beta-1b delays conversion to clinically definite and mcdonald $\mathrm{ms}$ in patients with clinically isolated syndromes. Neurology 2006, 67, 1242-1249. [CrossRef] [PubMed]

100. Huang, D.R. Challenges in randomized controlled trials and emerging multiple sclerosis therapeutics. Neurosci. Bull. 2015, 31, 745-754. [CrossRef] [PubMed]

101. Fenu, G.; Lorefice, L.; Frau, F.; Coghe, G.C.; Marrosu, M.G.; Cocco, E. Induction and escalation therapies in multiple sclerosis. Anti-Inflamm. Anti-Allergy Agents Med. Chem. 2015, 14, 26-34. [CrossRef]

102. Kipp, M.; Wagenknecht, N.; Beyer, C.; Samer, S.; Wuerfel, J.; Nikoubashman, O. Thalamus pathology in multiple sclerosis: From biology to clinical application. Cell. Mol. Life Sci. 2015, 72, 1127-1147. [CrossRef] [PubMed]

103. Calabresi, P.A.; Radue, E.W.; Goodin, D.; Jeffery, D.; Rammohan, K.W.; Reder, A.T.; Vollmer, T.; Agius, M.A.; Kappos, L.; Stites, T.; et al. Safety and efficacy of fingolimod in patients with relapsing-remitting multiple sclerosis (freedoms ii): A double-blind, randomised, placebo-controlled, phase 3 trial. Lancet Neurol. 2014, 13, 545-556. [CrossRef]

104. Greenberg, B.M.; Balcer, L.; Calabresi, P.A.; Cree, B.; Cross, A.; Frohman, T.; Gold, R.; Havrdova, E.; Hemmer, B.; Kieseier, B.C.; et al. Interferon beta use and disability prevention in relapsing-remitting multiple sclerosis. JAMA Neurol. 2013, 70, 248-251. [CrossRef] [PubMed]

105. Noyes, K.; Weinstock-Guttman, B. Impact of diagnosis and early treatment on the course of multiple sclerosis. Am. J. Manag. Care 2013, 19, s321-s331.

106. Shirani, A.; Zhao, Y.; Karim, M.E.; Evans, C.; Kingwell, E.; Van Der Kop, M.L.; Oger, J.; Gustafson, P.; Petkau, J.; Tremlett, H. Association between use of interferon beta and progression of disability in patients with relapsing-remitting multiple sclerosis. JAMA 2012, 308, 247-256. [CrossRef] [PubMed]

107. Rommer, P.S.; Stüve, O. Management of secondary progressive multiple sclerosis: Prophylactic treatment past, present, and future aspects. Curr. Treat. Options Neurol. 2013, 15, 241-258. [CrossRef] [PubMed]

108. Trojano, M.; Pellegrini, F.; Paolicelli, D.; Fuiani, A.; Zimatore, G.B.; Tortorella, C.; Simone, I.L.; Patti, F.; Ghezzi, A.; Zipoli, V.; et al. Real-life impact of early interferon $\beta$ therapy in relapsing multiple sclerosis. Ann. Neurol. 2009, 66, 513-520. [CrossRef] [PubMed]

109. Goodin, D.S.; Ebers, G.C.; Cutter, G.; Cook, S.D.; O'Donnell, T.; Reder, A.T.; Kremenchutzky, M.; Oger, J.; Rametta, M.; Beckmann, K.; et al. Cause of death in ms: Long-term follow-up of a randomised cohort, 21 years after the start of the pivotal ifn $\beta-1 b$ study. BMJ Open 2012, 2. [CrossRef] [PubMed]

110. Goodin, D.S.; Reder, A.T.; Ebers, G.C.; Cutter, G.; Kremenchutzky, M.; Oger, J.; Langdon, D.; Rametta, M.; Beckmann, K.; DeSimone, T.M.; et al. Survival in ms a randomized cohort study 21 years after the start of the pivotal ifn $\beta-1 b$ trial. Neurology 2012, 78, 1315-1322. [CrossRef] [PubMed]

111. Mitsdoerffer, M.; Kuchroo, V. New pieces in the puzzle: How does interferon-beta really work in multiple sclerosis? Ann. Neurol. 2009, 65, 487-488. [CrossRef] [PubMed]

112. The IFNB Multiple Sclerosis Study Group. Interferon beta-1b is effective in relapsing-remitting multiple sclerosis. I. Clinical results of a multicenter, randomized, double-blind, placebo-controlled trial. Neurology 1993, 43, 655-661.

113. The IFNB Multiple Sclerosis Study Group; The University of British Columbia MS/MRI Analysis Group. Interferon beta- $1 \mathrm{~b}$ in the treatment of multiple sclerosis: Final outcome of the randomized controlled trial. Neurology 1995, 45, 1277-1285.

114. Yong, V.W.; Giuliani, F.; Xue, M.; Bar-Or, A.; Metz, L.M. Experimental models of neuroprotection relevant to multiple sclerosis. Neurology 2007, 68, S32-S37. [CrossRef] [PubMed] 
115. Wolinsky, J.S.; Narayana, P.A.; O'Connor, P.; Coyle, P.K.; Ford, C.; Johnson, K.; Miller, A.; Pardo, L.; Kadosh, S.; Ladkani, D.; et al. Glatiramer acetate in primary progressive multiple sclerosis: Results of a multinational, multicenter, double-blind, placebo-controlled trial. Ann. Neurol. 2007, 61, 14-24. [CrossRef] [PubMed]

116. Wolinsky, J.S. Copolymer 1: A most reasonable alternative therapy for early relapsing-remitting multiple sclerosis with mild disability. Neurology 1995, 45, 1245-1247. [CrossRef] [PubMed]

117. Neuhaus, O.; Farina, C.; Wekerle, H.; Hohlfeld, R. Mechanisms of action of glatiramer acetate in multiple sclerosis. Neurology 2001, 56, 702-708. [CrossRef] [PubMed]

118. Ragheb, S.; Abramczyk, S.; Lisak, D.; Lisak, R. Long-term therapy with glatiramer acetate in multiple sclerosis: Effect on t-cells. Mult. Scler. 2001, 7, 43-47. [CrossRef] [PubMed]

119. Haas, J.; Korporal, M.; Balint, B.; Fritzsching, B.; Schwarz, A.; Wildemann, B. Glatiramer acetate improves regulatory $\mathrm{t}$-cell function by expansion of naive CD4(+)CD25(+)Foxp3(+)CD31(+) t-cells in patients with multiple sclerosis. J. Neuroimmunol. 2009, 216, 113-117. [CrossRef] [PubMed]

120. Johnson, K.P.; Brooks, B.R.; Cohen, J.A.; Ford, C.C.; Goldstein, J.; Lisak, R.P.; Myers, L.W.; Panitch, H.S.; Rose, J.W.; Schiffer, R.B.; et al. Copolymer 1 reduces relapse rate and improves disability in relapsing-remitting multiple sclerosis: Results of a phase iii multicenter, double-blind placebo-controlled trial. Neurology 1995, 45, 1268-1276. [CrossRef] [PubMed]

121. Gold, R.; Kappos, L.; Arnold, D.L.; Bar-Or, A.; Giovannoni, G.; Selmaj, K.; Tornatore, C.; Sweetser, M.T.; Yang, M.; Sheikh, S.I.; et al. Placebo-controlled phase 3 study of oral bg-12 for relapsing multiple sclerosis. N. Engl. J. Med. 2012, 367, 1098-1107. [CrossRef] [PubMed]

122. Moharregh-Khiabani, D.; Linker, R.A.; Gold, R.; Stangel, M. Fumaric acid and its esters: An emerging treatment for multiple sclerosis. Curr. Neuropharmacol. 2009, 7, 60-64. [CrossRef] [PubMed]

123. Albrecht, P.; Bouchachia, I.; Goebels, N.; Henke, N.; Hofstetter, H.H.; Issberner, A.; Kovacs, Z.; Lewerenz, J.; Lisak, D.; Maher, P.; et al. Effects of dimethyl fumarate on neuroprotection and immunomodulation. J. Neuroinflamm. 2012, 9. [CrossRef] [PubMed]

124. Palmer, A.M. Teriflunomide, an inhibitor of dihydroorotate dehydrogenase for the potential oral treatment of multiple sclerosis. Curr. Opin. Investig. Drugs 2010, 11, 1313-1323. [PubMed]

125. Korn, T.; Magnus, T.; Toyka, K.; Jung, S. Modulation of effector cell functions in experimental autoimmune encephalomyelitis by leflunomide-mechanisms independent of pyrimidine depletion. J. Leukoc. Biol. 2004, 76, 950-960. [CrossRef] [PubMed]

126. O'Connor, P.; Wolinsky, J.S.; Confavreux, C.; Comi, G.; Kappos, L.; Olsson, T.P.; Benzerdjeb, H.; Truffinet, P.; Wang, L.; Miller, A.; et al. Randomized trial of oral teriflunomide for relapsing multiple sclerosis. N. Engl. J. Med. 2011, 365, 1293-1303. [CrossRef] [PubMed]

127. Sanvito, L.; Constantinescu, C.S.; Gran, B. Novel therapeutic approaches to autoimmune demyelinating disorders. Curr. Pharm. Des. 2011, 17, 3191-3201. [CrossRef] [PubMed]

128. Yeh, E.A. Current therapeutic options in pediatric multiple sclerosis. Curr. Treat. Options Neurol. 2011, 13, 544-559. [CrossRef] [PubMed]

129. O'Connor, P.W.; Li, D.; Freedman, M.S.; Bar-Or, A.; Rice, G.P.A.; Confavreux, C.; Paty, D.W.; Stewart, J.A.; Scheyer, R. A phase ii study of the safety and efficacy of teriflunomide in multiple sclerosis with relapses. Neurology 2006, 66, 894-900. [CrossRef] [PubMed]

130. Confavreux, C.; O'Connor, P.; Comi, G.; Freedman, M.S.; Miller, A.E.; Olsson, T.P.; Wolinsky, J.S.; Bagulho, T.; Delhay, J.-L.; Dukovic, D.; et al. Oral teriflunomide for patients with relapsing multiple sclerosis (tower): A randomised, double-blind, placebo-controlled, phase 3 trial. Lancet Neurol. 2014, 13, 247-256. [CrossRef]

131. Vermersch, P.; Czlonkowska, A.; Grimaldi, L.M.; Confavreux, C.; Comi, G.; Kappos, L.; Olsson, T.P.; Benamor, M.; Bauer, D.; Truffinet, P.; et al. Teriflunomide versus subcutaneous interferon beta-1a in patients with relapsing multiple sclerosis: A randomised, controlled phase 3 trial. Mult. Scler. J. 2014, 20, 705-716. [CrossRef] [PubMed]

132. Brinkmann, V.; Davis, M.D.; Heise, C.E.; Albert, R.; Cottens, S.; Hof, R.; Bruns, C.; Prieschl, E.; Baumruker, T.; Hiestand, P.; et al. The immune modulator fty720 targets sphingosine 1-phosphate receptors. J. Biol. Chem. 2002, 277, 21453-21457. [CrossRef] [PubMed]

133. Mandala, S.; Hajdu, R.; Bergstrom, J.; Quackenbush, E.; Xie, J.; Milligan, J.; Thornton, R.; Shei, G.J.; Card, D.; Keohane, C.; et al. Alteration of lymphocyte trafficking by sphingosine-1-phosphate receptor agonists. Science 2002, 296, 346-349. [CrossRef] [PubMed] 
134. Matloubian, M.; Lo, C.G.; Cinamon, G.; Lesneski, M.J.; Xu, Y.; Brinkmann, V.; Allende, M.L.; Proia, R.L.; Cyster, J.G. Lymphocyte egress from thymus and peripheral lymphoid organs is dependent on s1p receptor 1. Nature 2004, 427, 355-360. [CrossRef] [PubMed]

135. Choi, J.W.; Gardell, S.E.; Herr, D.R.; Rivera, R.; Lee, C.W.; Noguchi, K.; Teo, S.T.; Yung, Y.C.; Lu, M.; Kennedy, G.; et al. Fty720 (fingolimod) efficacy in an animal model of multiple sclerosis requires astrocyte sphingosine 1-phosphate receptor 1 (s1p1) modulation. Proc. Natl. Acad. Sci. USA 2011, 108, 751-756. [CrossRef] [PubMed]

136. Cohen, J.A.; Barkhof, F.; Comi, G.; Hartung, H.P.; Khatri, B.O.; Montalban, X.; Pelletier, J.; Capra, R.; Gallo, P.; Izquierdo, G.; et al. Oral fingolimod or intramuscular interferon for relapsing multiple sclerosis. N. Engl. J. Med. 2010, 362, 402-415. [CrossRef] [PubMed]

137. Kappos, L.; Radue, E.W.; O'Connor, P.; Polman, C.; Hohlfeld, R.; Calabresi, P.; Selmaj, K.; Agoropoulou, C.; Leyk, M.; Zhang-Auberson, L.; et al. A placebo-controlled trial of oral fingolimod in relapsing multiple sclerosis. N. Engl. J. Med. 2010, 362, 387-401. [CrossRef] [PubMed]

138. Huang, B.; Wang, Q.T.; Song, S.S.; Wu, Y.J.; Ma, Y.K.; Zhang, L.L.; Chen, J.Y.; Wu, H.X.; Jiang, L.; Wei, W. Combined use of etanercept and $\mathrm{mtx}$ restores $\mathrm{CD} 4^{+} / \mathrm{CD}^{+}$ratio and tregs in spleen and thymus in collagen-induced arthritis. Inflamm. Res. 2012, 61, 1229-1239. [CrossRef] [PubMed]

139. Lenk, H.; Muller, U.; Tanneberger, S. Mitoxantrone: Mechanism of action, antitumor activity, pharmacokinetics, efficacy in the treatment of solid tumors and lymphomas, and toxicity. Anticancer Res. 1987, 7, 1257-1264. [PubMed]

140. Hartung, H.-P.; Gonsette, R.; Konig, N.; Kwiecinski, H.; Guseo, A.; Morrissey, S.P.; Krapf, H.; Zwingers, T. Mitoxantrone in progressive multiple sclerosis: A placebo-controlled, double-blind, randomised, multicentre trial. Lancet 2002, 360, 2018-2025. [CrossRef]

141. Edan, G.; Miller, D.; Clanet, M.; Confavreux, C.; Lyon-Caen, O.; Lubetzki, C.; Brochet, B.; Berry, I.; Rolland, Y.; Froment, J.C.; et al. Therapeutic effect of mitoxantrone combined with methylprednisolone in multiple sclerosis: A randomised multicentre study of active disease using mri and clinical criteria. J. Neurol. Neurosurg. Psychiatry 1997, 62, 112-118. [CrossRef] [PubMed]

142. Martinelli, V.; Radaelli, M.; Straffi, L.; Rodegher, M.; Comi, G. Mitoxantrone: Benefits and risks in multiple sclerosis patients. Neurol. Sci. 2009, 30, S167-S170. [CrossRef] [PubMed]

143. Sheremata, W.A.; Minagar, A.; Alexander, J.S.; Vollmer, T. The role of alpha-4 integrin in the aetiology of multiple sclerosis: Current knowledge and therapeutic implications. CNS Drugs 2005, 19, 909-922. [CrossRef] [PubMed]

144. Rice, G.P.A.; Hartung, H.P.; Calabresi, P.A. Anti- $\alpha 4$ integrin therapy for multiple sclerosis: Mechanisms and rationale. Neurology 2005, 64, 1336-1342. [CrossRef] [PubMed]

145. Klotz, L.; Gold, R.; Hemmer, B.; Korn, T.; Zipp, F.; Hohlfeld, R.; Kieseier, B.C.; Wiendl, H. Diagnosis of multiple sclerosis 2010 revision of the mcdonald criteria. Nervenarzt 2011, 82, 1302-1309. [CrossRef] [PubMed]

146. Jarius, S.; Hohlfeld, R.; Voltz, R. Diagnosis and therapy of multiple sclerosis-Update 2003. MMW Fortschr. Med. 2003, 145, 88-95. [PubMed]

147. Miller, D.H.; Khan, O.A.; Sheremata, W.A.; Blumhardt, L.D.; Rice, G.P.A.; Libonati, M.A.; Willmer-Hulme, A.J.; Dalton, C.M.; Miszkiel, K.A.; O'Connor, P.W. A controlled trial of natalizumab for relapsing multiple sclerosis. N. Engl. J. Med. 2003, 348, 15-23. [CrossRef] [PubMed]

148. Natalizumab: New drug. Multiple sclerosis: Risky market approval. Prescrire Int. 2008, 17, 7-10.

149. Frohman, E.M.; Racke, M.K.; Raine, C.S. Multiple sclerosis-the plaque and its pathogenesis. N. Engl. J. Med. 2006, 354, 942-955. [CrossRef] [PubMed]

150. Hauser, S.L.; Waubant, E.; Arnold, D.L.; Vollmer, T.; Antel, J.; Fox, R.J.; Bar-Or, A.; Panzara, M.; Sarkar, N.; Agarwal, S.; et al. B-cell depletion with rituximab in relapsing-remitting multiple sclerosis. N. Engl. J. Med. 2008, 358, 676-688. [CrossRef] [PubMed]

151. Kappos, L.; Li, D.; Calabresi, P.A.; O'Connor, P.; Bar-Or, A.; Barkhof, F.; Yin, M.; Leppert, D.; Glanzman, R.; Tinbergen, J.; et al. Ocrelizumab in relapsing-remitting multiple sclerosis: A phase 2, randomised, placebo-controlled, multicentre trial. Lancet 2011, 378, 1779-1787. [CrossRef]

152. Sorensen, P.S.; Lisby, S.; Grove, R.; Derosier, F.; Shackelford, S.; Havrdova, E.; Drulovic, J.; Filippi, M. Safety and efficacy of ofatumumab in relapsing-remitting multiple sclerosis: A phase 2 study. Neurology 2014, 82, 573-581. [CrossRef] [PubMed] 
153. Bleeker, W.K.; Munk, M.E.; Mackus, W.J.; van den Brakel, J.H.; Pluyter, M.; Glennie, M.J.; van de Winkel, J.G.; Parren, P.W. Estimation of dose requirements for sustained in vivo activity of a therapeutic human anti-cd20 antibody. Br. J. Haematol. 2008, 140, 303-312. [CrossRef] [PubMed]

154. ClinicalTrials.gov. Identifier: NCT02792218 and NCT02792231. Available online: https:/ /www.mdanderson. org/patients-family/diagnosis-treatment/clinical-trials.html (accessed on 20 June 2017).

155. U.S. Food \& Drug Administration (FDA). Drugs@fda: FDA Approved Drug Products. Available online: http: / / www.accessdata.fda.gov/scripts/cder/daf/index.cfm?event=overview.process\&varApplNo=761053 (accessed on 20 June 2017).

156. Cohen, J.A.; Coles, A.J.; Arnold, D.L.; Confavreux, C.; Fox, E.J.; Hartung, H.P.; Havrdova, E.; Selmaj, K.W.; Weiner, H.L.; Fisher, E.; et al. Alemtuzumab versus interferon beta $1 \mathrm{a}$ as first-line treatment for patients with relapsing-remitting multiple sclerosis: A randomised controlled phase 3 trial. Lancet 2012, 380, 1819-1828. [CrossRef]

157. Coles, A.J.; Twyman, C.L.; Arnold, D.L.; Cohen, J.A.; Confavreux, C.; Fox, E.J.; Hartung, H.P.; Havrdova, E.; Selmaj, K.W.; Weiner, H.L.; et al. Alemtuzumab for patients with relapsing multiple sclerosis after disease-modifying therapy: A randomised controlled phase 3 trial. Lancet 2012, 380, 1829-1839. [CrossRef]

158. Lycke, J. Monoclonal antibody therapies for the treatment of relapsing-remitting multiple sclerosis: Differentiating mechanisms and clinical outcomes. Ther. Adv. Neurol. Disord. 2015, 8, 274-293. [CrossRef] [PubMed]

159. McAllister, L.D.; Beatty, P.G.; Rose, J. Allogeneic bone marrow transplant for chronic myelogenous leukemia in a patient with multiple sclerosis. Bone Marrow Transplant. 1997, 19, 395-397. [CrossRef] [PubMed]

160. Mancardi, G.; Saccardi, R. Autologous haematopoietic stem-cell transplantation in multiple sclerosis. Lancet Neurol. 2008, 7, 626-636. [CrossRef]

161. Sormani, M.P.; Muraro, P.A.; Schiavetti, I.; Signori, A.; Laroni, A.; Saccardi, R.; Mancardi, G.L. Autologous hematopoietic stem cell transplantation in multiple sclerosis: A meta-analysis. Neurology 2017, 88, 2115-2122. [CrossRef] [PubMed]

162. Yamout, B.; Hourani, R.; Salti, H.; Barada, W.; El-Hajj, T.; Al-Kutoubi, A.; Herlopian, A.; Baz, E.K.; Mahfouz, R.; Khalil-Hamdan, R.; et al. Bone marrow mesenchymal stem cell transplantation in patients with multiple sclerosis: A pilot study. J. Neuroimmunol. 2010, 227, 185-189. [CrossRef] [PubMed]

163. Llufriu, S.; Sepulveda, M.; Blanco, Y.; Marin, P.; Moreno, B.; Berenguer, J.; Gabilondo, I.; Martinez-Heras, E.; Sola-Valls, N.; Arnaiz, J.A.; et al. Randomized placebo-controlled phase ii trial of autologous mesenchymal stem cells in multiple sclerosis. PLoS ONE 2014, 9, e113936. [CrossRef] [PubMed]

164. Correale, J.; Fiol, M. Bht-3009, a myelin basic protein-encoding plasmid for the treatment of multiple sclerosis. Curr. Opin. Mol. Ther. 2009, 11, 463-470. [PubMed]

165. Kang, Y.; Sun, Y.; Zhang, J.; Gao, W.; Kang, J.; Wang, Y.; Wang, B.; Xia, G. Treg cell resistance to apoptosis in DNA vaccination for experimental autoimmune encephalomyelitis treatment. PLOS ONE 2012, 7, e49994. [CrossRef] [PubMed]

166. Bar-Or, A.; Vollmer, T.; Antel, J.; Arnold, D.L.; Bodner, C.A.; Campagnolo, D.; Gianettoni, J.; Jalili, F.; Kachuck, N.; Lapierre, Y.; et al. Induction of antigen-specific tolerance in multiple sclerosis after immunization with DNA encoding myelin basic protein in a randomized, placebo-controlled phase $1 / 2$ trial. Arch. Neurol. 2007, 64, 1407-1415. [CrossRef] [PubMed]

167. Papadopoulou, A.; Von Felten, S.; Traud, S.; Rahman, A.; Quan, J.; King, R.; Garren, H.; Steinman, L.; Cutter, G.; Kappos, L.; et al. Evolution of ms lesions to black holes under DNA vaccine treatment. J. Neurol. 2012, 259, 1375-1382. [CrossRef] [PubMed]

168. Xiang, S.D.; Scholzen, A.; Minigo, G.; David, C.; Apostolopoulos, V.; Mottram, P.L.; Plebanski, M. Pathogen recognition and development of particulate vaccines: Does size matter? Methods 2006, 40,1-9. [CrossRef] [PubMed]

169. Xiang, S.D.; Selomulya, C.; Ho, J.; Apostolopoulos, V.; Plebanski, M. Delivery of DNA vaccines: An overview on the use of biodegradable polymeric and magnetic nanoparticles. Wiley Interdiscip. Rev. Nanomed. Nanobiotechnol. 2010, 2, 205-218. [CrossRef] [PubMed]

170. Cappellano, G.; Woldetsadik, A.D.; Orilieri, E.; Shivakumar, Y.; Rizzi, M.; Carniato, F.; Gigliotti, C.L.; Boggio, E.; Clemente, N.; Comi, C.; et al. Subcutaneous inverse vaccination with plga particles loaded with a mog peptide and il-10 decreases the severity of experimental autoimmune encephalomyelitis. Vaccine 2014, 32, 5681-5689. [CrossRef] [PubMed] 
171. Al-Ghobashy, M.A.; ElMeshad, A.N.; Abdelsalam, R.M.; Nooh, M.M.; Al-Shorbagy, M.; Laible, G. Development and pre-clinical evaluation of recombinant human myelin basic protein nano therapeutic vaccine in experimental autoimmune encephalomyelitis mice animal model. Sci. Rep. 2017, 7, 46468. [CrossRef] [PubMed]

172. Crowe, P.D.; Qin, Y.; Conlon, P.J.; Antel, J.P. Nbi-5788, an altered mbp83-99 peptide, induces a t-helper 2-like immune response in multiple sclerosis patients. Ann. Neurol. 2000, 48, 758-765. [CrossRef]

173. Hartung, H.P.; Kieseier, B.C.; Hemmer, B. Purely systemically active anti-inflammatory treatments are adequate to control multiple sclerosis. J. Neurol. 2005, 252, v30-v37. [CrossRef] [PubMed]

174. Kappos, L.; Comi, G.; Panitch, H.; Oger, J.; Antel, J.; Conlon, P.; Steinman, L.; Comi, G.; Kappos, L.; Oger, J.; et al. Induction of a non-encephalitogenic type $2 \mathrm{t}$ helper-cell autoimmune response in multiple sclerosis after administration of an altered peptide ligand in a placebo-controlled, randomized phase ii trial. Nat. Med. 2000, 6, 1176-1182. [PubMed]

175. Bielekova, B.; Goodwin, B.; Richert, N.; Cortese, I.; Kondo, T.; Afshar, G.; Gran, B.; Eaton, J.; Antel, J.; Frank, J.A.; et al. Encephalitogenic potential of the myelin basic protein peptide (amino acids 83-99) in multiple sclerosis: Results of a phase ii clinical trial with an altered peptide ligand. Nat. Med. 2000, 6, 1167-1175. [PubMed]

176. Perera, C.J.; Duffy, S.S.; Lees, J.G.; Kim, C.F.; Cameron, B.; Apostolopoulos, V.; Moalem-Taylor, G. Active immunization with myelin-derived altered peptide ligand reduces mechanical pain hypersensitivity following peripheral nerve injury. J. Neuroinflamm. 2015, 12, 28. [CrossRef] [PubMed]

177. Perera, C.J.; Lees, J.G.; Duffy, S.S.; Makker, P.G.; Fivelman, B.; Apostolopoulos, V.; Moalem-Taylor, G. Effects of active immunisation with myelin basic protein and myelin-derived altered peptide ligand on pain hypersensitivity and neuroinflammation. J. Neuroimmunol. 2015, 286, 59-70. [CrossRef] [PubMed]

178. Tian, D.H.; Perera, C.J.; Apostolopoulos, V.; Moalem-Taylor, G. Effects of vaccination with altered peptide ligand on chronic pain in experimental autoimmune encephalomyelitis, an animal model of multiple sclerosis. Front. Neurol. 2013, 4, 168. [CrossRef] [PubMed]

179. Lourbopoulos, A.; Deraos, G.; Matsoukas, M.; Touloumi, O.; Giannakopoulou, A.; Kalbacher, H.; Grigoriadis, N.; Apostolopoulos, V.; Matsoukas, J. Cyclic mog 35-55 ameliorates clinical and neuropathological features of experimental autoimmune encephalomyelitis. Bioorg. Med. Chem. 2017. [CrossRef] [PubMed]

180. Apostolopoulos, V.; Pietersz, G.A.; Loveland, B.E.; Sandrin, M.S.; McKenzie, I.F. Oxidative/reductive conjugation of mannan to antigen selects for $\mathrm{t} 1$ or $\mathrm{t} 2$ immune responses. Proc. Natl. Acad. Sci. USA 1995, 92, 10128-10132. [CrossRef] [PubMed]

181. Apostolopoulos, V.; Pietersz, G.A.; McKenzie, I.F. Cell-mediated immune responses to muc1 fusion protein coupled to mannan. Vaccine 1996, 14, 930-938. [CrossRef]

182. Apostolopoulos, V.; Pietersz, G.A.; Tsibanis, A.; Tsikkinis, A.; Drakaki, H.; Loveland, B.E.; Piddlesden, S.J.; Plebanski, M.; Pouniotis, D.S.; Alexis, M.N.; et al. Pilot phase iii immunotherapy study in early-stage breast cancer patients using oxidized mannan-muc1 [isrctn71711835]. Breast Cancer Res. 2006, 8, R27. [CrossRef] [PubMed]

183. Apostolopoulos, V.; Pietersz, G.A.; Tsibanis, A.; Tsikkinis, A.; Stojanovska, L.; McKenzie, I.F.; Vassilaros, S. Dendritic cell immunotherapy: Clinical outcomes. Clin. Transl. Immunol. 2014, 3, e21. [CrossRef] [PubMed]

184. Karanikas, V.; Hwang, L.A.; Pearson, J.; Ong, C.S.; Apostolopoulos, V.; Vaughan, H.; Xing, P.X.; Jamieson, G.; Pietersz, G.; Tait, B.; et al. Antibody and t cell responses of patients with adenocarcinoma immunized with mannan-muc1 fusion protein. J. Clin. Investig. 1997, 100, 2783-2792. [CrossRef] [PubMed]

185. Vassilaros, S.; Tsibanis, A.; Tsikkinis, A.; Pietersz, G.A.; McKenzie, I.F.; Apostolopoulos, V. Up to 15-year clinical follow-up of a pilot phase iii immunotherapy study in stage ii breast cancer patients using oxidized mannan-muc1. Immunotherapy 2013, 5, 1177-1182. [CrossRef] [PubMed]

186. Loveland, B.E.; Zhao, A.; White, S.; Gan, H.; Hamilton, K.; Xing, P.X.; Pietersz, G.A.; Apostolopoulos, V.; Vaughan, H.; Karanikas, V.; et al. Mannan-muc1-pulsed dendritic cell immunotherapy: A phase i trial in patients with adenocarcinoma. Clin. Cancer Res. 2006, 12, 869-877. [CrossRef] [PubMed]

187. Mitchell, P.L.; Quinn, M.A.; Grant, P.T.; Allen, D.G.; Jobling, T.W.; White, S.C.; Zhao, A.; Karanikas, V.; Vaughan, H.; Pietersz, G.; et al. A phase 2, single-arm study of an autologous dendritic cell treatment against mucin 1 in patients with advanced epithelial ovarian cancer. J. Immunother. Cancer 2014, 2, 16. [CrossRef] [PubMed] 
188. Day, S.; Tselios, T.; Androutsou, M.E.; Tapeinou, A.; Frilligou, I.; Stojanovska, L.; Matsoukas, J.; Apostolopoulos, V. Mannosylated linear and cyclic single amino acid mutant peptides using a small 10 amino acid linker constitute promising candidates against multiple sclerosis. Front. Immunol. 2015, 6, 136. [CrossRef] [PubMed]

189. Yannakakis, M.P.; Simal, C.; Tzoupis, H.; Rodi, M.; Dargahi, N.; Prakash, M.; Mouzaki, A.; Platts, J.A.; Apostolopoulos, V.; Tselios, T.V. Design and synthesis of non-peptide mimetics mapping the immunodominant myelin basic protein $\left(\mathrm{MBP}_{83-96}\right)$ epitope to function as t-cell receptor antagonists. Int. J. Mol. Sci. 2017, 18. [CrossRef] [PubMed]

(c) (C) 2017 by the authors. Licensee MDPI, Basel, Switzerland. This article is an open access article distributed under the terms and conditions of the Creative Commons Attribution (CC BY) license (http://creativecommons.org/licenses/by/4.0/). 